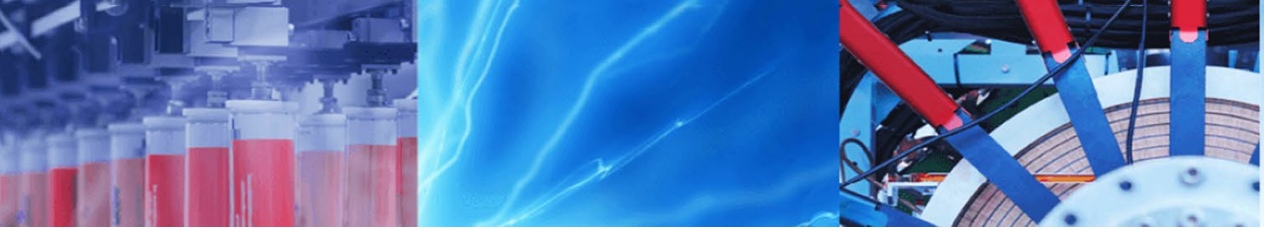

Review Paper

\title{
Fertilizers and nitrate pollution of surface and ground water: an increasingly pervasive global problem
}

\author{
Bijay-Singh $^{1}$ (D) Eric Craswell ${ }^{2}$
}

Received: 27 November 2020 / Accepted: 18 March 2021 / Published online: 31 March 2021

(C) The Author(s) 2021 OPEN

\begin{abstract}
Nitrate pollution of ground and surface water bodies all over the world is generally linked with continually increasing global fertilizer nitrogen (N) use. But after 1990, with more fertilizer $\mathrm{N}$ consumption in developing countries especially in East and South Asia than in the industrialized nations in North America and Europe, nitrate pollution of freshwaters is now increasingly becoming a pervasive global problem. In this review it has been attempted to review the research information generated during the last two decades from all over the world on different aspects of nitrate pollution of natural water bodies. It is now evident that not more than $50 \%$ of the fertilizer $\mathrm{N}$ is directly used by the crops to which it is applied. While a small portion may directly leach down and may reach ground and surface water bodies, a large proportion ends up in the soil organic $\mathrm{N}$ pool from where $\mathrm{N}$ is mineralized and is taken up by plants and/or lost via leaching during several decades. Present trends of nitrate pollution of freshwaters, therefore, reflect legacies of current and past applications of fertilizers and manures. Tools such as simulation models and the natural variation in the stable isotopes of $\mathrm{N}$ and oxygen are now being extensively used to study the contribution of fertilizers and other sources to nitrate enrichment of freshwaters. Impacts of agricultural stewardship measures are being assessed and nitrate enrichment of water bodies is being managed using modern digital models and frameworks. Improved water and fertilizer management in agroecosystems can reduce the contribution of fertilizers to nitrate pollution of water bodies but a host of factors determine the magnitude. Future research needs are also considered.
\end{abstract}

Keywords Fertilizer nitrogen · Nitrate · Water pollution · Fertilizer management · Ground water · Surface water · Soil nitrogen

\section{Introduction}

Nitrogen $(\mathrm{N})$ in the form of nitrate is a common pollutant in both surface and ground waters. Nitrate- $\mathrm{N}$ can readily leach down beyond the root zone in agricultural soils and reach the ground and surface waters. At levels exceeding the permissible limits, nitrate- $\mathrm{N}$ makes the ground water unfit for drinking purposes. In surface waters limited by $\mathrm{N}$, phytoplankton productivity is stimulated by nitrate- $\mathrm{N}$ resulting in eutrophication leading to widespread hypoxia and anoxia, loss of biodiversity and harmful algal blooms that can damage fisheries and pristine marine environments such as heritage coral reefs [1]. According to Howarth [2], as high as 10- to 15-fold increases in $\mathrm{N}$ flows in some areas are causing greatly increased coastal eutrophication. Glibert et al. [3] contended that the problem is exacerbated by the expansion in the use of urea fertilizer which is soluble and mobile in surface water flows.

Widespread pollution of water bodies by nitrate- $\mathrm{N}$ due agricultural intensification in the twentieth century in industrialized countries in North America and Western and Central Europe has been of major concern since early

Bijay-Singh, bijaysingh20@hotmail.com | ${ }^{1}$ Department of Soil Science, Punjab Agricultural University, Ludhiana 141004 , India. ${ }^{2} \mathrm{Fenner}$ School on Environment and Society, Australian National University, Canberra 2600, Australia. 
1970s [4]. It was a direct consequence of applying large quantities of fertilizer $\mathrm{N}$ in these countries. Globally, $60 \%$ of areas with elevated nitrate- $\mathrm{N}$ in ground water occur in croplands [5]. As only $20 \%$ of the total cultivated land is under irrigated agriculture and accounts for about $40 \%$ of the global food production, fertilizer $\mathrm{N}$ use and loss of nitrate- $\mathrm{N}$ to natural water bodies from the irrigated cropland is much higher than from rain-fed agriculture (http:// www.unesco.org/new/en/natural-sciences/environment/ water/wwap/facts-and-figures/all-facts-wwdr3/fact-24irrigated-land/; Accessed 27 January, 2021). Although spatial and temporal distribution of nitrate- $\mathrm{N}$ in ground water under cropland will be determined by fertilizer $\mathrm{N}$ use per unit area, percentage of area under cereal crops, vegetable and orchards, percentage of irrigated area, per capita agricultural production, livestock per unit area, population per unit area and annual mean temperature, global fertilizer $\mathrm{N}$ consumption is increasing almost linearly in response to increasing demand for staple cereal food grains and animal-derived food (Fig. 1). But after the late 1980s, in many developing countries in East and South Asia, fertilizer $\mathrm{N}$ consumption increased several fold more than in the developed regions, where levels have stabilized since 1990 (Fig. 1). For example, in 2018, China in East Asia and India in South Asia, having $36.8 \%$ of the global population, used $42.3 \%$ of $108.7 \mathrm{Mt}$ total fertilizer $\mathrm{N}$ consumed globally; North America and Europe consumed only 26.9\% (http://www.fao.org/faostat/en/\#data/RFN; Accessed 25 October, 2020). Of course, Africa and Oceania remained regions where fertilizer $\mathrm{N}$ consumption has been very low and is increasing at a very slow pace (Fig. 1). After 2015, fertilizer $\mathrm{N}$ consumption in East Asia started declining because China, the major fertilizer $\mathrm{N}$ consuming country, recognized the seriousness of the overuse of fertilizers and introduced the action plan for zero growth of fertilizer use [6]. The changes in fertilizer $\mathrm{N}$ consumption patterns in different parts of the world have discernible impacts on nitrate pollution of ground and surface water bodies in different regions. Thus, although leaching of nitrate- $\mathrm{N}$ from the soil-plant system is influenced also by climate, soil and other factors, in recent decades nitrate pollution of surface and ground water has emerged as a serious environmental issue in several countries in East and South Asia along with already affected regions in North America and western and central Europe [5]. Keeping in view that even in countries with low average fertilizer $\mathrm{N}$ consumption there exist regions with intensive agriculture and substantial fertilizer $\mathrm{N}$ use, nitrate pollution of ground and surface waters as linked with fertilizer $\mathrm{N}$ use is now a global issue.

The scope of the water quality problem as linked with fertilizer use is commonly only apparent when the offsite impacts of individual farms are aggregated at a range of scales-watershed, river basin, or global. Seen on a global scale, crop production represents the largest single factor perturbing the nitrogen cycle. Liu et al. [7] estimated that of the total annual global $\mathrm{N}$ flows into croplands of $136.6 \mathrm{Tg} \mathrm{N}$, almost $50 \%$ was contributed by fertilizer $\mathrm{N}$. They estimate that, of the total $148 \mathrm{Tg} \mathrm{N}$ year ${ }^{-1} \mathrm{~N}$ outflows, leaching accounts for $23 \mathrm{Tg} \mathrm{N}$ year $^{-1}$, and soil erosion for $24 \mathrm{Tg} \mathrm{N}_{\text {year }}{ }^{-1}$. Under aerobic soil conditions, $\mathrm{N}$ is readily converted to nitrate and much of the unused nitrate dissolves in rain and irrigation water, eventually leaching through the soil into underlying aquifers or surface waters. During 2004-2010,
Fig. 1 Fertilizer $\mathrm{N}$ consumption pattern since 1961 in different regions of the world. Data source: http://ifadata.fertilizer. org/ucSearch.aspx (Accessed 8 August, 2020)

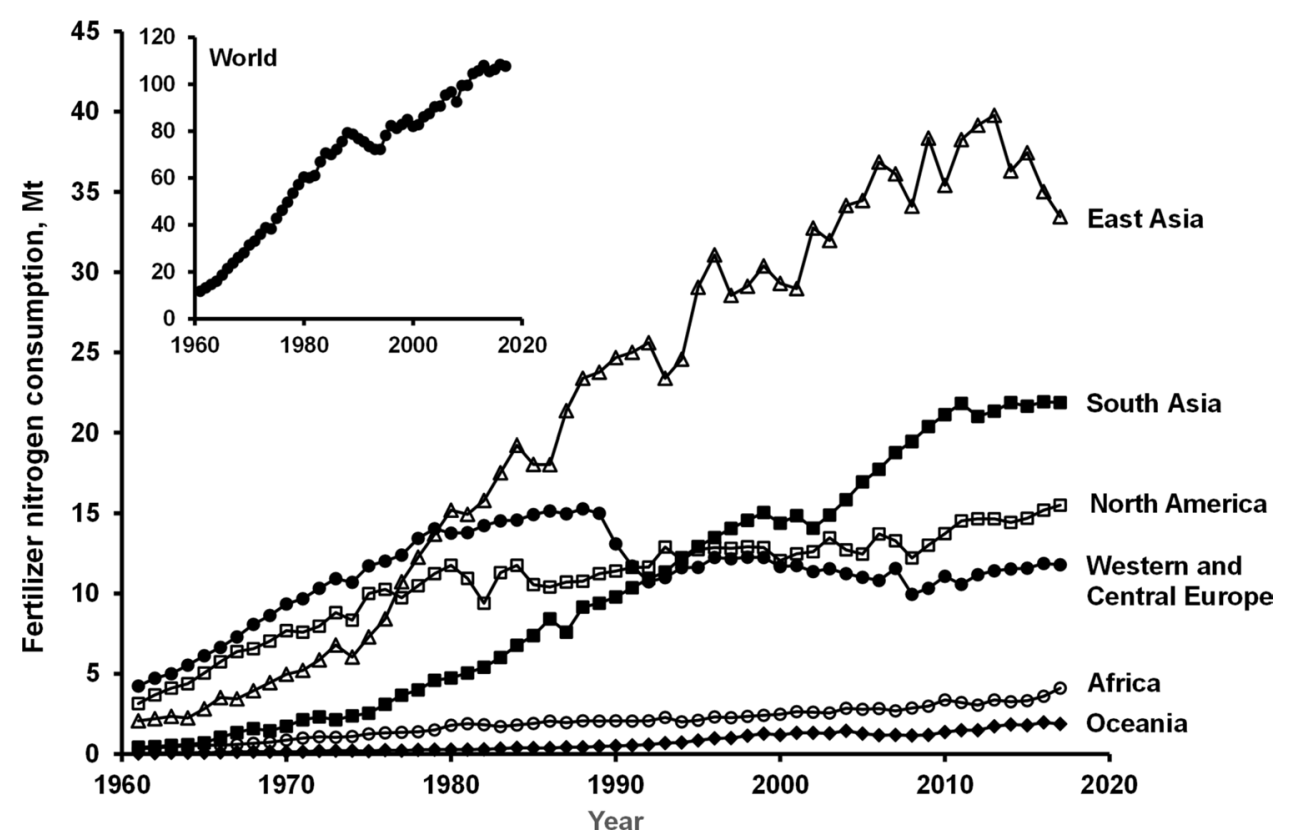


when China used the highest amount of fertilizer $\mathrm{N}$ in the world, Zhang et al. [8] analysed nitrate- $\mathrm{N}$ content in 62 shallow groundwater wells located in 29 Chinese Ecosystem Research Network field stations; 43 wells were in agroecosystems across a range of climatic zones where wheat, maize, soybean, rice and cotton were grown, and 19 wells were beneath forest ecosystems along the north-south transect of eastern China. It was found that average nitrate- $\mathrm{N}$ concentrations were significantly higher in the wells located under agro-ecosystems $\left(4.1 \pm 0.33 \mathrm{mg} \mathrm{L}^{-1}\right)$ than in those under the forest ecosystems $\left(0.5 \pm 0.04 \mathrm{mg} \mathrm{L}^{-1}\right)$. The nitrate- $\mathrm{N}$ concentration in 10 of the 43 wells the agricultural ecosystems was even higher than $10 \mathrm{mg} \mathrm{L}^{-1}$. Rainfall or irrigation combined with excessive fertilizer $\mathrm{N}$ use in wheat, corn and cotton resulted in high groundwater nitrate- $\mathrm{N}$ in agro-ecosystems. Due to relatively high nitrate-N level in shallow wells located in the agroecosystems, farmers were advised to drill deep drinking water wells to reduce the risk of nitrate pollution.

Substantial amounts of nitrates are also produced from the organic waste generated by farm animals and the sewage produced by cities, and these can also reach groundwater bodies. In areas such as intensive feedlots, livestock waste constitutes a potent source of excess nutrients flowing into the environment. Although the concern that increased application of mineral fertilizers is polluting both surface waters and aquifers is substantiated by observed correlations relating expanded use of fertilizers and nitrate leaching [9, $10]$, the direct impact of the application of fertilizers on the nitrate content of waters is difficult to ascribe precisely. Nitrate concentrations in groundwater may vary widely from place to place even with uniform farm management practices [11]. Although Galloway et al. [12] made an all-encompassing estimate that about $25 \%$ of $\mathrm{N}$ applied to agricultural ecosystems escapes to contaminate water resources, there remains considerable uncertainty about the transit time of applied $\mathrm{N}$ between the topsoil and groundwater due to inadequate mechanistic understanding of the role of different $\mathrm{N}$ transformations in the soil [13]. During the last two decades, there has been noteworthy progress in quantifying the role of fertilizers in polluting water bodies through increased understanding of how nitrate- $\mathrm{N}$ originating from fertilizers reaches freshwaters. Use of isotopes and simulation models have proved very helpful in achieving increased precision in our understanding on these issues. This review is an attempt to collate recent researches on different aspects of fertilizer $\mathrm{N}$ use related nitrate pollution of water bodies from all over the world, including countries experiencing expanded fertilizer $\mathrm{N}$ use in recent decades.

\section{Leaching of fertilizer $\mathbf{N}$ from the soil-plant system and its contribution to nitrate pollution in water bodies}

How and in what proportion of nitrate- $\mathrm{N}$ originating from fertilizer $\mathrm{N}$ applied to agricultural crops reaches surface and ground water has remained an important question since it has been known that excess nitrate- $\mathrm{N}$ in water bodies due intensive fertilizer use is not desirable. Once fertilizer $\mathrm{N}$ is applied to the soil as urea or ammonium, it is transformed biochemically to nitrate, which is liable to leach beyond the soil-plant system to reach water bodies. In general, $10-30 \%$ of fertilizer $\mathrm{N}$ applied in modern agricultural systems is lost [14] but fate of $\mathrm{N}$ in the subsurface environment depends upon several biochemical and bio-physico-chemical processes. Due to the complex relationship between land use activities, fertilizer $\mathrm{N}$ management, rainfall, irrigation management, soil $\mathrm{N}$ dynamics and soil features, accurate quantification of nitrate leaching to surface and ground water bodies has remained a challenging task.

Recently, Ju and Zhang [15] reviewed the nitrogen cycling and environmental impacts in upland agricultural soils in North China and reported that large amount of nitrate- $\mathrm{N}$ has accumulated in the vadose-zone under agricultural soils because of excess $\mathrm{N}$ fertilization in the past three decades, and this nitrate- $\mathrm{N}$ is prone to occasional leaching leading to groundwater nitrate contamination. In a meta-analysis conducted by Zhou et al. [16], about $70 \%$ of the nitrate-N under maize, wheat and vegetables was distributed in the soil layers deeper than $1 \mathrm{~m}$ root zone and it was attributed to application of fertilizer and manure $\mathrm{N}$ excess of crop demand. The nitrate$\mathrm{N}$ below the root zone could not be utilized by the next crop $[17,18]$ and it leached to deeper soil layers during heavy rainfall or irrigation events [19]. Fertilizer $\mathrm{N}$ application at rates more than $80 \mathrm{~kg} \mathrm{~N} \mathrm{ha}^{-1}$, which exceeded $\mathrm{N}$ demand of maize grown in tropical agricultural soils, Jankowski et al. [20] observed accumulation of leached nitrate- $\mathrm{N}$ in deep soil layers. In a meta-analysis based on 32 studies on maize and wheat from all over the world, Zhou and Butterbach-Bahl [21] reported that on average, $22 \%$ and $15 \%$ of applied fertilizer $\mathrm{N}$ to wheat and maize are leached as nitrate- $\mathrm{N}$, respectively. However, average area-scaled nitrate- $\mathrm{N}$ losses were $29 \mathrm{~kg} \mathrm{~N} \mathrm{ha}^{-1}$ from wheat and $57.4 \mathrm{~kg} \mathrm{~N} \mathrm{ha}^{-1}$ from maize fields; primarily because of average higher $\mathrm{N}$ application rates for maize $\left(249 \mathrm{~kg} \mathrm{~N} \mathrm{ha}^{-1}\right)$ as compared to wheat $\left(171 \mathrm{~kg} \mathrm{~N} \mathrm{ha}^{-1}\right)$.

Data on leaching losses of $\mathrm{N}$ from the Broadbalk Experiment at Rothamsted Experimental Station in UK, in which $\mathrm{N}$ treatments have been repeated on the same plots since 1843 reveal that when fertilizer $\mathrm{N}$ is applied 
at rates above that required for optimum yield, a large amount of nitrate- $\mathrm{N}$ is leached from the soil [22]. On the basis of field data compiled from 324 site-year combinations from around the world, Wang et al. [23] inferred that at many sites nitrate leaching increases exponentially rather than linearly in response to increasing fertilizer $\mathrm{N}$ application. They computed a fertilizer-induced soil nitrate leaching emission factor as the nitrate-N leaching in fertilized plot more than in the no-N plot expressed as a percentage of the applied fertilizer $\mathrm{N}$; it did not remain constant, but increased rapidly with increasing rates of $\mathrm{N}$ application. The Intergovernmental Panel on Climate Change is using a fixed $30 \%$ soil nitrate leaching emission factor in its description of the fate of applied fertilizer N. However, Wang et al. [23] found that soil nitrate leaching emission factors varied with fertilizer $\mathrm{N}$ level and thus reported much lower nitrate- $\mathrm{N}$ leaching from different levels of fertilizer $\mathrm{N}$ application under wheat and maize croplands in major countries than the estimates based on the fixed $30 \%$ emission factor (Table 1).

Differentiating between the nitrate pollution caused by fertilizer $\mathrm{N}$ application and that caused by use of organic manures in crop production is a difficult challenge, but it must be faced if evidence-based steps are to be implemented to improve water quality. Nitrate-N leaching losses from organic manures and sludges are generally lower than those from $\mathrm{N}$ fertilizers except for effluents like pig slurry containing high proportion of mineral $\mathrm{N}$ [24]. However, when organic amendments are applied on a long-term basis, nitrate-N leaching may or may not be lower than those from mineral fertilizers because repeated application of organic amendments generally leads to gradual build-up of soil organic matter. For example, in 135 year-old plots at Rothamsted Experimental Station receiving either $235 \mathrm{~kg} \mathrm{~N} \mathrm{ha}^{-1}$ year ${ }^{-1}$ as farmyard manure or $144 \mathrm{~kg} \mathrm{~N} \mathrm{ha}^{-1}$ year $^{-1}$ as fertilizer $\mathrm{N}$, total soil $\mathrm{N}$ in the
0-23 cm soil layer in the farmyard manure plot accumulated to $7680 \mathrm{~kg} \mathrm{~N} \mathrm{ha}^{-1}$ compared to $2570 \mathrm{~kg} \mathrm{~N} \mathrm{ha}^{-1}$ in the fertilizer treated plot [25]. Estimated nitrate-N leaching losses were $124 \mathrm{~kg} \mathrm{~N} \mathrm{ha}^{-1}$ year $^{-1}$ from the farmyard manure plot and only $25 \mathrm{~kg} \mathrm{~N} \mathrm{ha}^{-1}$ year $^{-1}$ from the fertilizer treated plot. Although actual amount of $\mathrm{N}$ leached from agro-ecosystems is determined by soil and climatic conditions, management practices and the form of fertilizer $\mathrm{N}$ applied, Di and Cameron [24] concluded that nitrate leaching under different land use systems followed the order: cut grassland $<$ grazed pastures, arable cropping $<$ ploughing of pastures $<$ vegetables.

The nitrate concentration in groundwater should be directly related to land use management practices only in situations where relatively stable groundwater tables and negligible water flow exist. In most cases, however, nitrate concentration in an aquifer dynamically shifts within a watershed because regional water cycles can produce subregions of recharge and discharge in all directions. For example, Liu et al. [11] observed that nitrate-N concentration in the ground water in northern China was poorly related to land use type on the ground, although the region was a typically high nitrate yielding one. Recent developments that take into account the complexities of watersheds, and the impacts of factors such as denitrification, utilise modern remote sensing and modelling techniques to provide valuable insights into groundwater pollution with nitrate-N [26].

During the early days of intensive fertilizer $\mathrm{N}$ use, the distribution of nitrate- $\mathrm{N}$ in soil profiles under agricultural crops was used to get an idea of nitrate-N leaching to water bodies [27]. In the last decade, Zhao et al. [28] studied nitrate distribution in plots of long-term experiments to examine the pollution potential associated with different fertilizer management treatments. Application of fertilizer $\mathrm{N}$ in five long-term experiments representing a range of soils, climates and cropping systems (wheat
Table 1 Nitrate-N leaching as estimated by fixed $30 \%$ soil nitrate leaching emission factor as used by Intergovernmental Panel on Climate Change (IPCC) and by following the soil nitrate leaching emission factors, which vary with fertilizer $\mathrm{N}$ as proposed by Wang et al. [23] for agricultural land under wheat and maize production in major countries

\begin{tabular}{lllll}
\hline $\mathrm{N}$ rate $\left(\mathrm{kg} \mathrm{N} \mathrm{ha}^{-1}\right)$ & Country-crops & Mean N rate $\left(\mathrm{kg} \mathrm{N} \mathrm{ha}^{-1}\right)$ & Nitrate-N leaching $\left(\mathrm{kg} \mathrm{N} \mathrm{ha}^{-1}\right)$ \\
\hline & & & IPCC & Wang et al. [23] \\
$0<\mathrm{N} \leq 50$ & 10 & 33.33 & 10.00 & 1.29 \\
$50<\mathrm{N} \leq 100$ & 16 & 78.56 & 23.57 & 4.17 \\
$100<\mathrm{N} \leq 150$ & 9 & 131.12 & 39.33 & 8.99 \\
$\mathrm{~N}>150$ & 11 & 204.53 & 61.36 & 19.00 \\
Total & 46 & 109.13 & 32.74 & 8.04 \\
\hline
\end{tabular}

Modified from Wang et al. [23]

Fertilizer $\mathrm{N}$ input and arable land area data for maize and wheat were obtained from the International Fertilizer Industry Association (IFA) and the Food and Agriculture Organization (FAO), respectively 
and/or maize)—some of them irrigated, resulted in substantial accumulation of nitrate- $\mathrm{N}$ in the soil profile up to 2-3 $\mathrm{m}$ depth than under no-N control or long-term fallowed plots. The risk of nitrate pollution of ground water increased with increasing dose of fertilizer $\mathrm{N}$, but application of balanced amount of N, P and $\mathrm{K}$ fertilizers rather than $\mathrm{N}$ alone led to significant reduction in nitrate- $\mathrm{N}$ accumulation in the soil profile. Lysimeter studies, statistical data analysis and models further improved our understanding of the key processes involved in nitrate leaching from agricultural lands. In recent decades, there has been noticeable advancement in our understanding of the fate of fertilizer $\mathrm{N}$ in relation to nitrate enrichment of groundwater and surface water bodies through sophisticated techniques involving ${ }^{15} \mathrm{~N}$-labeled fertilizer and distinguishing the contribution of fertilizers vis-à-vis other sources through monitoring the natural variations in the stable isotopes of $\mathrm{N}$ and $\mathrm{O}$.

\subsection{Potential nitrate-N leaching from fertilizer $\mathbf{N}$ applied to agricultural land}

The fate of fertilizer $\mathrm{N}$ applied to agroecosystems is schematically shown in Fig. 2. Nitrogen is taken up by plant roots or is lost via leaching and in gaseous forms from the small mineral-N pool consisting of nitrate and ammonium ions. While applied fertilizer $\mathrm{N}$ directly contributes to this pool, it is continuously being replenished through mineralization of organic $\mathrm{N}$ contained in the large soil $\mathrm{N}$ pool. Only a portion of the applied fertilizer $\mathrm{N}$ is directly used by the crop to which it is applied; another portion is lost through different mechanisms including leaching as nitrate from the soil-plant system but a substantial portion becomes a part of the large pool of organically bound $\mathrm{N}$ in the soil. Based on data from over 800 experiments, Chien et al. [29] found that plants could recover only $51 \%$ of the fertilizer $\mathrm{N}$ applied to cereal crops, and when applied at high rates,

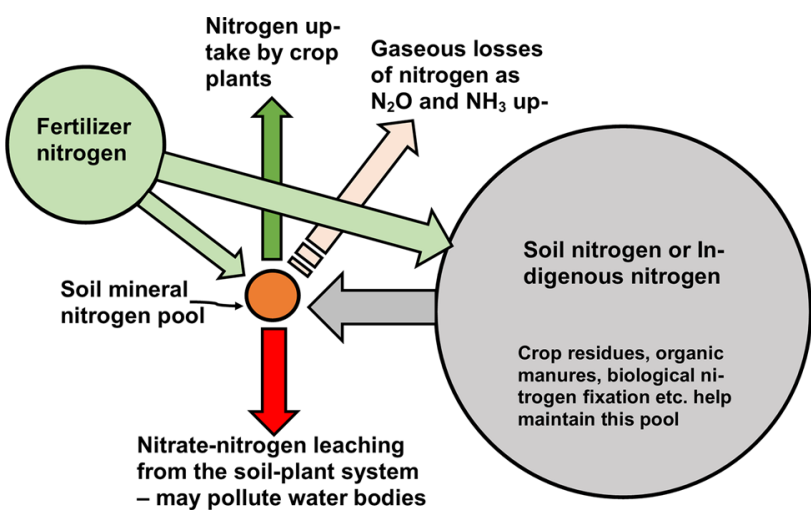

Fig. 2 Schematic diagram of the fate of fertilizer $\mathrm{N}$ applied to agricultural soils the average recovery of fertilizer $\mathrm{N}$ by crop plants may be even lower. Based on data generated in 93 studies conducted all over the world, Ladha et al. [30] concluded that average fertilizer ${ }^{15} \mathrm{~N}$ recovery in the grain and straw in maize, rice and wheat in the first growing season was 40, 44 and $45 \%$, respectively. Overall recovery among regions and crops was $44 \%$ (572 data points). In different cropping systems, after the first crop to which fertilizer ${ }^{15} \mathrm{~N}$ was applied, the average recovery of ${ }^{15} \mathrm{~N}$ in $2 \mathrm{nd}$ to 6 th subsequent crops has been reported to be $3.3 \%, 1.3 \%, 1.0 \%$, $0.4 \%$ and $0.5 \%$, respectively [31-33]. Thus, the cumulative recovery of ${ }^{15} \mathrm{~N}$ fertilizer applied to a crop in the first and five subsequent crops is around $50 \%$. As the amount of ${ }^{15} \mathrm{~N}$ in the roots becomes negligible after the sixth crop, it alludes to that much of the remaining $50 \%$ of the applied fertilizer ${ }^{15} \mathrm{~N}$ gets immobilized in the soil $\mathrm{N}$ pool. Only a portion of the fertilizer $\mathrm{N}$ is directly lost from the cropping system via leaching and/or in gaseous forms (nitrous oxide and ammonia) during the first copping season; in subsequent seasons ${ }^{15} \mathrm{~N}$ from the soil $\mathrm{N}$ pool is mineralized over several years and becomes available for uptake by crop plants or loss from the soil-plant system.

Dourado-Neto et al. [34] conducted a ${ }^{15} \mathrm{~N}$-recovery experiment in 13 diverse tropical agro-ecosystems and estimated the total recovery of one single ${ }^{15} \mathrm{~N}$ application of inorganic $\mathrm{N}$ during three to six growing seasons. It was observed that during the first growing season, an average of $79 \%$ of $\mathrm{N}$ in the crop was derived from soil N. Only $21 \%$ was derived from the applied fertilizer. Based on a metaanalysis of 217 field-scale studies on temperate grain agroecosystems that followed the stable isotope ${ }^{15} \mathrm{~N}$ in crops and soil, Gardner and Drinkwater [35] also revealed that even when large doses of fertilizer $\mathrm{N}$ were applied, contribution of soil to uptake of $\mathrm{N}$ by the crops was around $60 \%$. Even when optimum fertilizer $\mathrm{N}$ rates are applied, the processes of supplying $\mathrm{N}$ to crop plants and loss of nitrate$\mathrm{N}$ via leaching from the soil-plant system are dominated by the mineralization-immobilization turnover of soil N. As large contribution of soil $\mathrm{N}$ to uptake of $\mathrm{N}$ by crop plants is achieved through continuous supply of mineral $\mathrm{N}$ to the mineral- $\mathrm{N}$ pool of the soil, possible losses of nitrate- $\mathrm{N}$ generated from soil $\mathrm{N}$ are very small as in the case of natural ecosystems [36]. Therefore, when applied fertilizer $\mathrm{N}$ rates in agroecosystems are more than the optimum dose, crop uptake of $\mathrm{N}$ may not increase substantially but a proportion of fertilizer $\mathrm{N}$ (depending upon the fertilizer $\mathrm{N}$ rate) may be lost as nitrate- $\mathrm{N}$ leaching directly from the mineral $\mathrm{N}$ pool (Fig. 2) as regulated by climate and hydrology of the location. When fertilizer $\mathrm{N}$ is applied at rates that match crop $\mathrm{N}$ demand, there are virtually no or minimal direct leaching losses of applied fertilizer-N [37].

In two intact lysimeters under continuous sugar beet-winter wheat crop rotation during 1982 to 2012, 
Sebilo et al. [38] studied the long-term fate of ${ }^{15} \mathrm{~N}$ labeled fertilizer in the soil-plant system. In 1982, both crops received a one-time ${ }^{15} \mathrm{~N}$-labeled tracer application equivalent to a fertilizer application rate of 120 and $150 \mathrm{~kg} \mathrm{~N} \mathrm{ha}^{-1}$ for wheat and sugar beet, respectively, but later on annual $\mathrm{N}$ fertilization rate for both the crops was $120 \mathrm{~kg} \mathrm{~N} \mathrm{ha}^{-1}$. Three decades after application of ${ }^{15} \mathrm{~N}$ labelled fertilizer, $61-65 \%$ of the applied fertilizer $\mathrm{N}$ was taken up by plants but only $8-12 \%$ of the applied $\mathrm{N}$ had leaked towards the hydrosphere (Fig. 3). A large portion of the applied fertilizer ${ }^{15} \mathrm{~N}$ was rapidly integrated with soil $\mathrm{N}$ pool. Although three years after its application, 32 to $37 \%$ of the ${ }^{15} \mathrm{~N}$ fertilizer was found in the soil $\mathrm{N}$ pool [38], even after 28 years the percentage of $\mathrm{N}$ derived from ${ }^{15} \mathrm{~N}$ fertilizers in the soil $\mathrm{N}$ pool was $12-15 \%$ (Fig. 3). Oxygen $(\mathrm{O})$ isotope measurements $\left(\delta^{18} \mathrm{O}\right)$ on nitrate- $\mathrm{N}$ in seepage water collected at 2-m depth below the root zone confirmed that ${ }^{15} \mathrm{~N}$ enriched nitrate was derived from mineralization of soil organic matter. It was predicted that remaining fertilizer $\mathrm{N}$ still residing in the soil will continue to become available for crop uptake as well as leaching as nitrate- $\mathrm{N}$ towards groundwater for at least another five decades. It does not mean that short-term land use and fertilizer management changes including optimization of fertilizer $\mathrm{N}$ rates will not reduce leaching of nitrate-N from crop production systems [39]. However, the present trends in nitrate concentrations in ground water under agricultural regions in different parts of the world also reflect the legacies of current and past applications of fertilizers and manures during the past several decades.
Zhou et al. [16] estimated nitrate- $N$ accumulation in the soil profile up to $4 \mathrm{~m}$ depth at 141 sites in semi-humid crop lands in China and found that the amounts under different crops were in the increasing order as: wheat $\left(453 \pm 39 \mathrm{~kg} \mathrm{ha}^{-1}\right)$, maize $\left(749 \pm 75 \mathrm{~kg} \mathrm{ha}^{-1}\right)$, open field vegetables $\left(1191 \pm 89 \mathrm{~kg} \mathrm{ha}^{-1}\right)$, solar plastic-roofed vegetables $\left(1269 \pm 114 \mathrm{~kg} \mathrm{ha}^{-1}\right)$, orchards $\left(2155 \pm 330 \mathrm{~kg} \mathrm{ha}^{-1}\right)$. Similar quantities of nitrate- $\mathrm{N}$ were found to be accumulated in the vadose zone deeper than $4 \mathrm{~m}$. Huge nitrate- $\mathrm{N}$ accumulations were observed due to over use of fertilizers and/or manures and declining water table in the region. Van Meter et al. [40] analysed long-term (1957-2010) soil data throughout the Mississippi River Basin in U.S.A. At the watershed scale, they reported accumulation of 25-70 $\mathrm{kg} \mathrm{N} \mathrm{ha}^{-1}$ year $^{-1}$. A simple modelling exercise revealed that $142 \mathrm{Tg} \mathrm{N}$ of soil organic $\mathrm{N}$ accumulated in the basin over a 30-year span will result in biogeochemical lag time of 35 years for $99 \%$ legacy soil $\mathrm{N}$ even if the fertilizer $\mathrm{N}$ application in agricultural production in the basin was completely stopped. Soil as a net $\mathrm{N}$ sink clearly plays an important role in regulating nitrate pollution of surface and ground water bodies.

\subsection{Using nitrogen and oxygen isotopes to identify sources of nitrate- $\mathrm{N}$ and contribution of fertilizers to nitrate pollution of water bodies}

Useful information regarding sources of nitrate- $\mathrm{N}$ in water bodies, particularly ground water, can potentially be obtained from variations in stable $\mathrm{N}$ isotope ratios $\left({ }^{15} \mathrm{~N} /{ }^{14} \mathrm{~N}\right)$ because $\mathrm{N}$ sources such as atmospheric $\mathrm{N}_{2}$,
Fig. 3 Fate of fertilizer $\mathrm{N}$ labeled with ${ }^{15} \mathrm{~N}$ in two intact lysimeters under sugar beet-winter wheat rotation 3 decades after application of fertilizer. Data source: Sebilo et al. [38]

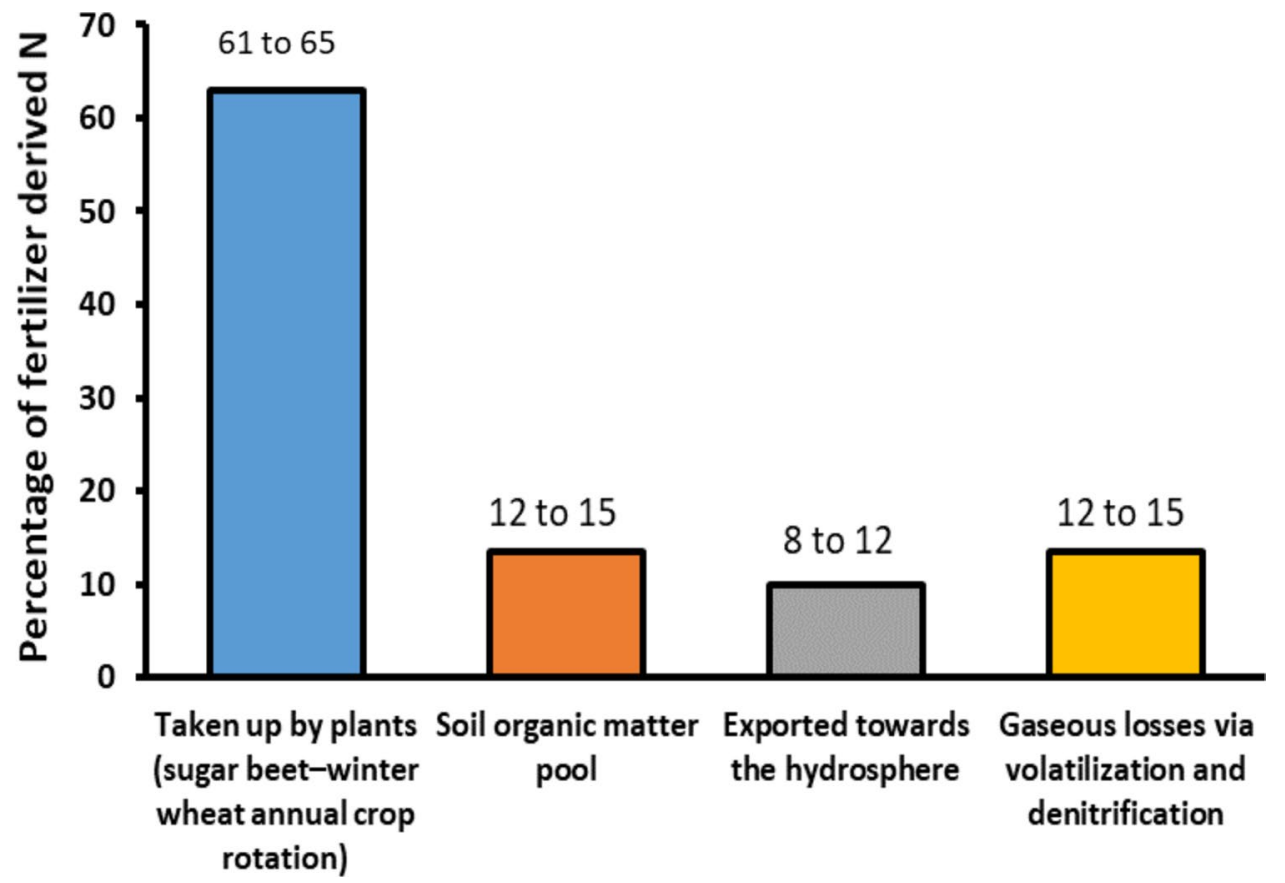

SN Applied Sciences a SPRINGER NATURE journal 
mineral fertilizers and organic manures possess widely different isotope compositions. Natural ${ }^{15} \mathrm{~N}$ abundances of $\mathrm{N}\left(\delta^{15} \mathrm{~N}\right)$ in surface and groundwater bodies reflect the integrated results of interactions between $\mathrm{N}$ sources and $\mathrm{N}$ isotope fractionations [41], and can provide information on the dominant contamination source-fertilizer, manure or soil N. Choi et al. [42] reviewed the subject and suggested that adequate information on the dominant source of nitrate- $\mathrm{N}$ in the ground water may not become available from the single measurement of $\delta^{15} \mathrm{~N}$ because the isotopic composition of nitrate- $\mathrm{N}$ in the groundwater is determined not only by its sources but also by any isotope fractionation by nitrification and denitrification that may occur during its generation or transport to groundwater. Since the origin of nitrate- $\mathrm{N}$ needs to interpreted in the context of the entire $\mathrm{N}$ cycle, Choi et al. [42] concluded that instead of a single $\delta^{15} \mathrm{~N}$ measurement, correlation between the nitrate- $\mathrm{N}$ concentration in the ground water and $\delta^{15} \mathrm{~N}$ provided better information about source of nitrate-N. Based on data available in the literature, it was inferred that when the nitrate- $\mathrm{N}$ concentration is consistently less than $3 \mathrm{mg} \mathrm{L}^{-1}$ along with $\delta^{15} \mathrm{~N}$ between +5 and $+8 \%$, source of nitrate- $\mathrm{N}$ is natural soil and it indicates that ground water is not contaminated (Fig. 4). For groundwater to be contaminated with nitrate- $\mathrm{N}$ originating from mineral fertilizers, nitrate- $\mathrm{N}$ concentration over $3 \mathrm{mg} \mathrm{L}^{-1}$ will be negatively correlated with $\delta^{15} \mathrm{~N}$ values between -3 and $+5 \%$, the widely accepted range for chemical fertilizers [43]. When groundwater is mainly contaminated with manure-derived nitrate- $\mathrm{N}$, nitrate- $\mathrm{N}$ concentration more

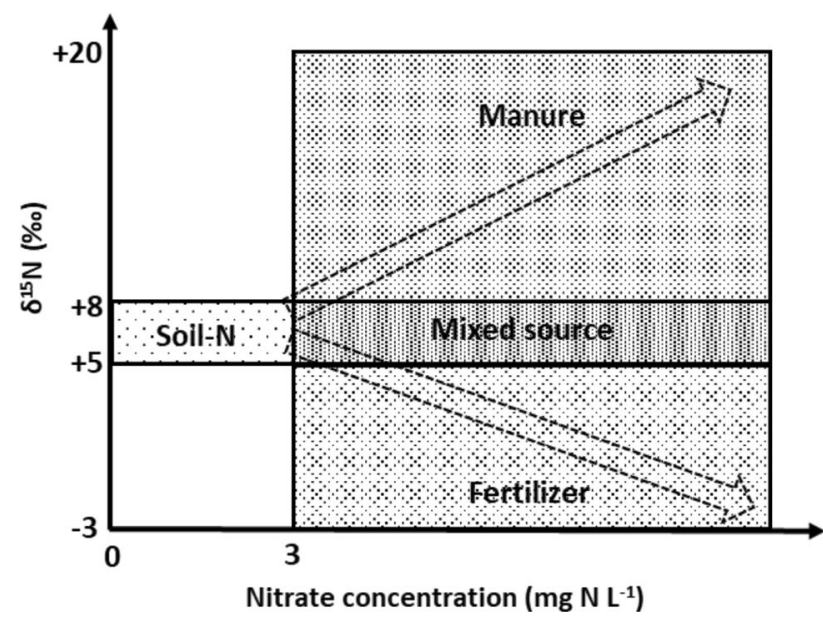

Fig. 4 Typical relationships between concentration and $\delta^{15} \mathrm{~N}$ of groundwater nitrate- $\mathrm{N}$ for different sources of nitrate-N. Above $3 \mathrm{mg}$ nitrate- $\mathrm{N} \mathrm{L}^{-1}$, a positive correlation between concentration of nitrate- $\mathrm{N}$ and $\delta^{15} \mathrm{~N}$ indicates the ${ }^{15} \mathrm{~N}$-enriched source such as organic manures, whereas ${ }^{15} \mathrm{~N}$-depleted sources such as mineral fertilizers result in a negative correlation. Modified from Choi et al. [42] than $3 \mathrm{mg} \mathrm{L}^{-1}$ should be correlated positively with $\delta^{15} \mathrm{~N}$ values above $+8 \%$ o (Fig. 4) $[42,43]$. It seems that these inferences should be valid for all soil types, agricultural systems and management scenarios of irrigation water and fertilizer $\mathrm{N}$.

In recent years, $\delta^{15} \mathrm{~N}$ has been combined with $\delta^{18} \mathrm{O}$ to reduce the uncertainties of nitrogen isotope in source apportionment and identification of nitrate source [44]. While the $\delta^{18} \mathrm{O}$ value of nitrate fertilizer is $22 \%$ o $\pm 3 \%$, soil $\mathrm{N}$ possesses $\delta^{18} \mathrm{O}$ values between $-5 \%$ and $+5 \%$. The values of $\delta^{18} \mathrm{O}$ in manure and sewage are lower than $15 \%$ [45], but the process of nitrification as well as ratio of $\delta^{18} \mathrm{O}-\mathrm{O}_{2}$ and $\delta^{18} \mathrm{O}-\mathrm{H}_{2} \mathrm{O}$ determine the $\delta^{18} \mathrm{O}$ in water bodies. Mixing proportion of nitrates originating from different sources in the ground water is revealed from a plot between nitrate- $\mathrm{N}$ concentrations versus isotopic composition of nitrate [46]. In case no positive or negative relationship is observed, it either indicates no simple mixing of nitrates from different sources or isotope values have been predominantly influenced due to a particular biological process. Since $\delta^{18} \mathrm{O}$ in nitrate ranges between +20 and $+70 \%$ o, $+17 \%$ ond $+25 \%$, and lower than $+15 \%$ o depending upon origin of nitrate from precipitation, synthetic nitrate fertilizer and nitrification of reduced $\mathrm{N}$ fertilizers, respectively, it can help distinguish nitrate- $\mathrm{N}$ from these three category of sources possessing similar range of $\delta^{15} \mathrm{~N}[47]$.

Zhang et al. [44] reviewed the research on source identification for nitrate pollution of natural water using $\mathrm{N}$ and $O$ isotopes. The work of Ding et al. [48] and Zhang et al. [49] showed that nitrate concentration in wastewater from farms and in rivers is directly correlated with the use of large amounts of mineral fertilizers. Using $\delta^{15} \mathrm{~N}$ and $\delta^{18} \mathrm{O}$ for source identification of nitrate- $\mathrm{N}$, mineral fertilizers have been identified as the main source in Yellow River Basin $\left(7.5 \times 10^{5} \mathrm{~km}^{2}\right)$ and Songhua River Basin $\left(5.6 \times 10^{5}\right.$ $\left.\mathrm{km}^{2}\right)$ in China, Lake Winnipeg $\left(2.45 \times 10^{4} \mathrm{~km}^{2}\right)$ in Canada, Guadalhorce River Basin $\left(3.2 \times 10^{3} \mathrm{~km}^{2}\right)$ in Spain, and lowland agricultural catchment of the River Wensum in Norfolk in eastern England [50-54].

In the East Tiaoxi River system in China, Jin et al. [55] used natural variation in the stable isotopes of $\mathrm{N}$ and $\mathrm{O}$ in combination with a Bayesian isotope mixing model and revealed that in the lower reaches of the river basin, fertilizer $\mathrm{N}$ contributed the most nitrate- $\mathrm{N}$ to water body. In the Yanggu County of the Gangwon Province in the north-eastern Korea, the Haean basin comprised of forests (58.0\%), vegetable fields (27.6\%), rice paddy fields $(11.4 \%)$ and others (3.0\%). In this basin, Kim et al. [56] estimated that nitrate- $\mathrm{N}$ concentration in the groundwater ranged between 4.2 and $15.2 \mathrm{mg} \mathrm{L}^{-1}$ under vegetable fields and between 0 and $10.7 \mathrm{mg} \mathrm{L}^{-1}$ under rice fields. Groundwaters with nitrate- $\mathrm{N}$ concentration more than $10 \mathrm{mg} \mathrm{L}^{-1}$ were 
found to possess $\delta^{15} \mathrm{~N}$ values of nitrate between 5.2 and $5.9 \%$ and $\delta^{18} \mathrm{O}$ values of nitrate between 2.7 and $4.6 \%$, thereby revealing that nitrate- $\mathrm{N}$ originated from mineralization of soil organic matter in which fertilizer $\mathrm{N}$ was incorporated through $\mathrm{N}$ substitution. Zhang et al. [57] traced nitrate pollution sources and transformations in surfaceand ground-waters using $\mathrm{N}$ and $\mathrm{O}$ isotopes in North China Plain and found that in the surface water bodies the main sources of nitrate- $\mathrm{N}$ were fertilizers and sewage, whereas soil-N and sewage were the prominent sources of nitrate- $\mathrm{N}$ in the groundwater during the dry season. However, during the wet season, nitrate- $\mathrm{N}$ produced due to fertilizer application will be readily leached by precipitation to the groundwater.

\section{Simulation models for studying nitrate pollution of water bodies}

Simulation models constitute efficient tools not only for predicting and managing nitrate- $\mathrm{N}$ pollution of surface and ground waters but also for understanding the physical, chemical and biological processes defining nitrate- $\mathrm{N}$ transport from the soil-plant system to water bodies. Several models have been developed focusing either on nitrate leaching in the root zone [58-62] or on mobility and fate of nitrate-N in the unsaturated zone [63, 64]. Some of the models used in the last two decades to simulate dynamics of water and $\mathrm{N}$ in the soil are: soil-crop model (STICS) [65-67], Root Zone Water Quality Model (RZWQM) [68], Agricultural Production Systems SIMulator (APSIM) [69], Cropping System Simulation Model (CropSyst) [70], Soil Water Balance Model (SWB-Sci) [71], Soil and Water Assessment Tool (SWAT) [72]. These models along with some simple models dealing with water and nitrate$\mathrm{N}$ production functions have also been used to study the impacts of fertilizer management (rate, time of application, source), precipitation pattern, irrigation strategies, and soil types on nitrate-N leaching in soils [73]. Most of these models, however, simulated fairly simplified scenarios such as one single soil type $[59,60,62]$ or layered soil types $[61$, $66,74-78]$ in a vertical two dimensional domain.

The best simulation models for nitrate- $\mathrm{N}$ in groundwater are the conceptual models that integrate the components of watershed hydrology, land use cover to compute the spatial distribution of on-ground $\mathrm{N}$ loadings, assessment of all $\mathrm{N}$ sources and their allocation to the different land cover classes, description of the nitrogen dynamics in the unsaturated zone soil, realistic estimation of nitrate$\mathrm{N}$ leaching to groundwater, groundwater flow system, accounting for groundwater-surface water interactions, and description of the fate of nitrate-N including transport processes in the groundwater $[65,79-85]$. Almasri [86] has described a general conceptual framework for the management of groundwater contamination from nitrate-N. It utilizes models for studying the fate of nitrate- $\mathrm{N}$ and its transport in the unsaturated and saturated zones to simulate nitrate- $\mathrm{N}$ concentration at the critical receptors.

To study $\mathrm{N}$ enrichment of surface water bodies, spatially-distributed and process-based watershed models are increasingly being used [87]. Since quantification of export of $\mathrm{N}$ from watershed is not an easy task due to the complexity of transport pathways [88], these models estimate $\mathrm{N}$ flux by combining processes such as water movement, sediment transport, crop growth and $\mathrm{N}$ cycling and by dividing watershed into multiple discrete units or subwatershed to control the spatial variability of the sources. For example, at the catchment scale, several researchers [72, 89-91] have found SWAT (Soil and Water Assessment Tool) to be a robust model in predicting both losses of $\mathrm{N}$ from source areas $[92,93]$ and in quantifying $N$ retention by streams and rivers within a sub-watershed [87].

Ledoux et al. [65] used the STICS-MODCOU-NEWSAM modelling chain to study the transport of nitrate-N originating from fertilizer use in crop production to surface and ground water bodies in the Seine river basin in France. But due to the large uncertainty attached to the simulation results, low sensitivity of predicted nitrate contamination in aquifers was observed primarily because of long transfer time through unsaturated zone and aquifers. $\mathrm{Li}$ et al. [87] used SWAT model to quantify how relative percentages of different types of agricultural land use influenced $\mathrm{N}$ export from a subtropical watershed in China. It was revealed that several sub-watersheds located close to the watershed mouth and occupying only $18 \%$ of the watershed area contributed most (40.7\%) to the total N export from the watershed. Further, among different subwatersheds, more than $70 \%$ variability of $\mathrm{N}$ input from the watershed to the river network was explained by the percentage of agricultural land under upland crops (such as maize and wheat) and lowland rice, and the number of cattle. To assess global $\mathrm{N}$ pollution in rivers, He et al. [94] developed and used a terrestrial $\mathrm{N}$ cycle model with a 24-h time step and $0.5^{\circ}$ spatial resolution to estimate $\mathrm{N}$ leaching from soil layers in farmlands, grasslands, and natural lands based on data on fertilizer use, population distribution, land cover, and social census. The data collected from 61 locations in catchment area of several major rivers all over the world showed that $\mathrm{N}$ loading in the rivers was proportional to the size of the watershed as well as any serious nitrate- $\mathrm{N}$ pollution that occurred in the catchment area due to intensive crop production activities and precipitation surpluses.

Eltarabily et al. [95] used the MODFLOW and MT3D groundwater modelling system to simulate nitrate-N leaching to ground water as well as groundwater flow 
in the Nile Delta aquifer in Egypt. It was revealed that groundwater contamination by nitrate- $\mathrm{N}$ occurred at shallow depths $(40 \mathrm{~m})$ due to extensive use of fertilizer $\mathrm{N}$ and flood irrigation for growing food crops. The modelling system also indicated that implementation of best fertilizer management practices should be able to reduce and control the amount of nitrate-N leaching into the shallow groundwater in the study area. Marinov and Marinov [96] simulated biogeochemical dynamics of the water and $\mathrm{N}$ in the soil-plant system and flow of nitrate-N to the ground water by coupling a 1D water transfer model for the unsaturated soil, a biochemical $\mathrm{N}$ transformation model for the soil, and a 2D model for dispersion of $\mathrm{N}$ in the groundwater. Simulations with this model system suggested that high crop yields along with minimal $\mathrm{N}$ loading to soils and groundwater can be achieved by creating an optimal balance between the amount of fertilizers and water applied to crops as well as the amount of nitrate- $\mathrm{N}$ and water used by plants. It may take decades for nitrate$\mathrm{N}$ leached from the agricultural soils to discharge into freshwaters due to long time lag in the unsaturated and saturated zone $[97,98]$. Current environmental strategies often do not consider this time lag [97], thereby leading to inappropriate controls and conflicts between policy makers, environmentalists and industry. Using two separate models to simulate transport of nitrate- $\mathrm{N}$ in the unsaturated and saturated zones along with a GIS groundwater flow model, Wang et al. [99] studied the nitrate-N lag time in the ground water system in UK and revealed that the peak nitrate-N loading around 1983 has affected most of the study area but it will arrive at the water table in some of the groundwater catchment for a pumping borehole within the following 34 years.

\section{Nitrate pollution of surface water bodies}

As nitrate-N content higher than the permitted concentration of $10 \mathrm{mg} \mathrm{L}^{-1}$ in groundwater used as source of drinking water can be serious threat to human health, nitrate- $\mathrm{N}$ enrichment of groundwater has been widely researched as diffuse pollution due to application of $\mathrm{N}$ via fertilizers and organic manures to agricultural lands [100]. However, eutrophication of lakes, reservoirs, ponds and coastal water bodies due to enrichment with $\mathrm{N}$ originating from fertilizers as non-point source pollution also leads to high fish mortality and algal blooms, which may adveresely affect the contribution of aquaculture to food security and rural incomes in many developing countries. It is increasingly being considered as a serious threat to water quality by reducing biodiversity and other valuable aquatic ecosystem functions [101]. In fact, for many freshwater and coastal marine ecosystems all over the world, eutrophication due to excessive $\mathrm{N}$ loading from anthropogenic activities is now a primary water quality issue [102]. Nitrogen lost from the landscape via surface runoff as well as subsurface drainage or leaching gets transported into surface water systems [103]. Factors which influence availability of soil N [104], movement of water [105], and gaseous losses of $\mathrm{N}$ via denitrification $[106,107]$ often dictate export of $\mathrm{N}$ to water bodies from a watershed in which $\mathrm{N}$ is applied to agricultural fields through fertilizer or manure.

Non-point source $\mathrm{N}$ pollution of surface waters, such as streams, is positively correlated with agricultural land use in their watersheds $[88,108,109]$. In fact, increased loading of streams with $\mathrm{N}$ from agricultural lands is associated with anthropogenic $\mathrm{N}$ application to crops in the form of fertilizers and manures $[93,110,111]$. Several researchers $[16,112,113]$ have reported that application of fertilizer $\mathrm{N}$, particularly at levels in excess of crop $\mathrm{N}$ removal rate, leads to increased losses of $\mathrm{N}$ to surface water bodies. Hill and Bolgrien [110] and Zhou et al. [114] reported that due to alterations in soil surface conditions and land management practices, dry land cropping increases $\mathrm{N}$ loading to streams from excessive application of fertilizers and manures more than lowland rice. Urea $\mathrm{N}$ applied to crops may reach sensitive coastal water via overland transport and provide $\mathrm{N}$ nutrition to some harmful algal bloom species. Due to global increase in urea use during 1970-2000, incidences of paralytic shellfish poisoning caused by harmful algal bloom species were documented by Glibert et al. [3].

The impact of non-point source pollution due to fertilizer use in agro-ecosystems may escalate as nitrate- $\mathrm{N}$ enters the watersheds and eventually the major river basins. It then becomes a regional issue as it can lead to eutrophication of coastal water $[115,116]$. In Table 2 are shown $\mathrm{N}$ inputs in major rivers of the world and $\mathrm{N}$ exports to coastal waters. Interestingly, $17-92 \%$ of the annual N input into the rivers was due to agriculture. Even in coastal waters, the contribution of agriculture to $\mathrm{N}$ exports was from 2 to $83 \%$. The limited contributions of agriculture to the $\mathrm{N}$ flows in the cases of the Amazon and Zaire reflect the relatively limited agricultural development in their catchments. For the Ganges and the Chinese rivers the large $\mathrm{N}$ inputs reflect the intensification of agriculture and presumably the expansion in fertilizer use over the past few decades.

\section{Macro hotspots}

The four hotspots discussed below are examples of major agricultural areas and illustrate some of the significant surface and groundwater quality problems associated with fertilizer use, and show the importance of policy and 
Table 2 Contribution of agriculture to nitrogen input into major rivers of the world and export to coastal waters

\begin{tabular}{|c|c|c|c|c|}
\hline \multirow[t]{2}{*}{ River (Country) } & \multicolumn{2}{|l|}{$\mathrm{N}$ input into rivers } & \multicolumn{2}{|c|}{$\mathrm{N}$ export to coastal waters } \\
\hline & Annual input, $\mathrm{kg} \mathrm{N} \mathrm{km}^{-2}$ & $\begin{array}{l}\text { Contribution } \\
\text { of agricul- } \\
\text { ture, } \%\end{array}$ & $\begin{array}{c}\text { Annual input, } \\
\text { kg N km }\end{array}$ & $\begin{array}{l}\text { Contribution } \\
\text { of agricul- } \\
\text { ture, } \%\end{array}$ \\
\hline Mississipi (USA) & 7489 & 89 & 597 & 63 \\
\hline Amazon (Brazil) & 3034 & 17 & 692 & 6 \\
\hline Nile (Egypt) & 3601 & 67 & 268 & 37 \\
\hline Zaire (Zaire) & 3427 & 18 & 632 & 9 \\
\hline $\begin{array}{l}\text { Zambezi (Zambia, Zim- } \\
\text { babwe, Mozambique) }\end{array}$ & 3175 & 47 & 330 & 2 \\
\hline Rhine (Germany) & 13,941 & 77 & 2795 & 49 \\
\hline Po (Italy) & 9060 & 81 & 1841 & 56 \\
\hline Ganges (India) & 9366 & 81 & 1269 & 55 \\
\hline Changjiang (China) & 11,823 & 92 & 2237 & 83 \\
\hline Huanghe (China) & 5159 & 88 & 214 & 24 \\
\hline
\end{tabular}

Adapted from van Drecht et al. [115] governance arrangements, particularly the important role of national versus international institutions.

\subsection{The Yangtze River basin in Central China}

The Yangtze or Chang Jiang is one of the three largest rivers in the world. It is now one of the most polluted rivers in the world due to discharge of industrial wastes and application of large amounts of fertilizers in farming in its catchment area [117]. Based on data available from monitoring stations for the period 1958-1985, it was found that nitrate- $\mathrm{N}$ concentration in the middle reaches of the Yangtze increased after the agricultural reforms of 1978 [118]. Yan et al. [119] estimated that fertilizer $\mathrm{N}$ inputs to the Yangtze watershed increased from $400 \mathrm{kt} \mathrm{N}$ in 1968 to $6000 \mathrm{kt} \mathrm{N}$ in 1997. During this period, the nitrate concentration and $\mathrm{N}$ load in the river increased about ten-fold in line with the intensification of agriculture and the use of mineral fertilizers replacing traditional green manure and labour-intensive organic fertilizers. From 1983 onwards, only $\mathrm{N}$ fertilizers were used in the catchment area of Yangtze. Recently, Chen et al. [120] linked the MARINA 2.0 (Model to Assess River Input of Nutrient to seAs) and the WOFOST (WOrld FOod STudy) models to estimate the contribution of crop production systems to $\mathrm{N}$ enrichment of the Yangtze River and revealed that about $6,000 \mathrm{Gg}$ of dissolved inorganic $\mathrm{N}$ originating from Yangtze basin entered the river in 2012. Half of this amount originated from the production of rice, wheat and vegetables to which $\mathrm{N}$ is supplied largely through mineral fertilizers.

\subsection{The Punjab, India}

Unprecedented progress in agricultural production in the Punjab province in north-western India since the onset of Green Revolution in early 1970 s could become possible due to several fold increase in fertilizer use besides intensification of agriculture in terms of adopting high yielding varieties, mechanization of field operations, using efficient plant protection techniques, and very high level of ground water development [121]. Irrigated wheat and wetland rice are grown in the Punjab in annual rotation in deep alluvial soils containing less than $0.5 \%$ organic carbon and sandy loam and loamy sand as the dominant textures [122]. While negligible losses of nitrate- $\mathrm{N}$ beyond $2 \mathrm{~m}$ depth have been recorded when ${ }^{15} \mathrm{~N}$-labelled potassium nitrate was applied as fertilizer during the wheat season [123], $\mathrm{N}$ remaining in the profile and that applied in the rice season is preferentially leached beyond rooting zone because wetland rice receives about $150 \mathrm{~cm}$ irrigation in addition to $33 \mathrm{~cm}$ of average annual rainfall; a large fraction of the applied water percolates down through the soil profile. Interestingly, due to high percolation rates, soil under rice experiences alternating aerobic-anaerobic cycles that facilitate production of nitrate unlike in ideal rice soils. Thus the nitrate $\mathrm{N}$ content in the groundwater in Punjab has been consistently increasing since 1975 when samples were analysed for the first time [124, 125]. Using data generated by reconnaissance of nitrate content in shallow ground waters, the Central Ground Water Board of India categorized Punjab region as the high risk zone with respect to nitrate pollution of groundwater [126]. Chhabra et al. [127] used a remote sensing and GIS approach based on data pertaining to fertilizer use, soil 
properties and rainfall at $1-\mathrm{km}^{2}$ grid size, and $\mathrm{N}$ loss coefficients derived from published $\mathrm{N}$ dynamics studies to reveal that about $29 \%$ of the applied fertilizer $\mathrm{N}$ to rice is lost as nitrate in coarse textured soils of Punjab. The weighted average nitrate- $\mathrm{N}$ loss via leaching in Punjab was estimated to be more than $50 \mathrm{~kg} \mathrm{ha}^{-1}$ year $^{-1}$.

\subsection{The Mississippi River Basin}

Drainage waters from a vast basin with intensive crop production activity end up in the Mississippi river in the United States of America. It has been estimated that while fertilizer use in the Mississippi River basin increased sixfold during 1955-1970 to 1980-1999, the nitrate enrichment of the Gulf of Mexico increased three times during the same period [128]. The nitrate created dead zones of bottom water hypoxia in the Gulf, with consequent fish mortality. State and Federal authorities in a Mississippi River/Gulf of Mexico Watershed Nutrient Task Force agreed that the export of nitrate should be reduced by $30 \%$ by 2015 [129]. Subsequent analysis suggested that to meet the goal set of a reduced dead zone area of $5000 \mathrm{~km}^{2}$ by 2015 would require a $45 \%$ annual reduction of nitrate and phosphate flows [130].

\subsection{The Baltic Sea}

The Baltic Sea is a relatively shallow salty body of water, which has a history of hypoxia for the past 10,000 years, but according to Zillén et al. [131], the hypoxia zone increased four-fold since 1960. Elevated riverine nutrient loads originating from diffuse agricultural sources constitute the major sources of increased nutrient inputs in the Baltic Sea [132]. According to Helsinki Commission [133], 70-90\% of the diffuse total $\mathrm{N}$ load was due to crop production activities. Drainage waters from an area of $1.75 \times 10^{6} \mathrm{~km}^{2}$ with a population of 90 million from 14 countries and with agricultural practices, intensities and nutrient losses varying across the basin end up in the Baltic Sea [134]. The average surplus flow of nutrients into the Baltic from food, feed and fertilizers amounted to 1.8 million tons $\mathrm{N}$ in 2002-2005 annually. Although unable to differentiate the extent of fertilizer $\mathrm{N}$ runoff from other nutrient sources, Asmala et al. [134] suggested that the best approach to reduce nutrient flows was to improve fertilizer use efficiency at the farm level. By performing simulations with SWAT model for six catchments with major agricultural crop production systems in the Baltic Sea drainage basin, Thodsen et al. [135] estimated that a change in mineral fertilizer use of $\pm 20 \%$ increased watershed nitrate- $\mathrm{N}$ loads between 0 and $\pm 13 \%$.

\section{Reducing nitrate pollution of water bodies by improving crop and fertilizer management}

The regional and national issues associated with surface and groundwater pollution due to fertilizer use in crop production revolve around both ineffective policies and inadequate technologies. In both developed and developing countries, there are difficulties in persuading farmers to adopt management practices which can result in reduced non-point source pollution due to fertilizer use. Also, there exist difficult trade-offs between food security and farm income on the one hand and increased risk of water pollution due to fertilizer use on the other hand. These trade-offs can be minimized but not eliminated [136]. Dinnes et al. [137] who reviewed N management strategies to reduce nitrate leaching in tile-drained soils concluded that to ensure that surface and ground waters achieve a quality acceptable to society, several strategies based on efficient management of fertilizer $\mathrm{N}$ as well as appropriate modification of soil management practices in conjunction with inherent physical, chemical and biological properties of the soil will be required.

Understanding response of nitrate-N leaching from agricultural fields to local field scale management as well as broader environmental drivers such as climate and soil can be helpful in reducing the contribution of fertilizer $\mathrm{N}$ to pollution of freshwater bodies. Eagle et al. [138] conducted a meta-analysis with 388 observations from maize cropping in the North America and revealed that average reduction in nitrate- $\mathrm{N}$ leaching observed by applying $100 \mathrm{~kg} \mathrm{~N} \mathrm{ha}^{-1}$ less fertilizer $\mathrm{N}$ rate was comparable to the effects of $100 \mathrm{~mm}$ less annual precipitation, $10 \mathrm{~g} \mathrm{~kg}^{-1}$ more soil C, or replacing continuous corn with corn-soybean rotation. Under average conditions, cutting fertilizer $\mathrm{N}$ rate by $10 \mathrm{~kg} \mathrm{~N} \mathrm{ha}^{-1}$ resulted in reduced average nitrate- $\mathrm{N}$ losses by $1.0 \mathrm{~kg} \mathrm{~N} \mathrm{ha}^{-1}$. But with $100 \mathrm{~mm}$ rise in annual precipitation, average nitrate-N leaching increased by $9 \mathrm{~kg} \mathrm{~N} \mathrm{ha}^{-1}$ year $^{-1}$. Quemada et al. [139] conducted a meta-analysis by creating a database with 279 observations to study the effect of improved water and fertilizer management, use of cover crops and improved fertilizer technologies on leaching of nitrate- $\mathrm{N}$ in irrigated agriculture. Improvement in water management (adjusting water application to crop needs, deficit irrigation, improved irrigation schedules, improved irrigation technologies, and mulched soil) had the largest (58\%) effect on reducing nitrate-N leaching, and it was significantly different from other strategies. While improved fertilizer management (using recommended fertilizer rates, reducing recommended fertilizer rates, optimized timing of fertilizer application, 
and fertigation) reduced nitrate-N leaching by $39 \%$, effect of improvement in fertilizer technologies (controlled release fertilizers and nitrification inhibitors) was only $24 \%$. Replacing a fallow with a non-legume cover crop reduced leaching of nitrate- $\mathrm{N}$ by $50 \%$ but using a legume cover crop did not affect nitrate-N leaching. Replacing excessive fertilizer $\mathrm{N}$ application with recommended rates reduced nitrate- $\mathrm{N}$ leaching by $43 \%$. In irrigated agroecosystems, even application of fertilizer $\mathrm{N}$ at recommended rates doubled the extent of nitrate$\mathrm{N}$ leaching as compared to in the unfertilized controls. However, factors other than fertilizer $\mathrm{N}$ application rate determined the nitrate leaching losses because by applying less than the recommended rates for fertilizer $\mathrm{N}$, a broad range in nitrate- $\mathrm{N}$ leaching $(<10$ to $150 \mathrm{~kg}$ nitrate- $\mathrm{N} \mathrm{ha}^{-1}$ ) was observed. Interestingly, fertigation that allows improvement in the timing of fertilizer $\mathrm{N}$ application did not exhibit a significant effect in reducing nitrate- $\mathrm{N}$ leaching. The meta-analysis conducted by Quemada et al. [139], therefore, convincingly proved that while the risk of nitrate leaching from irrigated cropping systems is high, optimum management practices may reduce the possibility of nitrate pollution of freshwaters due to fertilizer use.

On sandy soils in England, reduction in leaching losses of nitrate- $\mathrm{N}$ from agricultural fields to $10 \mathrm{~kg} \mathrm{ha}^{-1}$ and contribution of nitrate- $\mathrm{N}$ to groundwater at $1 \mathrm{~m}$ depth by $57 \%$ was achieved by limiting fertilizer $\mathrm{N}$ application to crop requirements or to amounts as per regulations for nitrate vulnerable zones [140, 141]. Vervloet et al. [142] analysed observational data for the period 1950-2011 for two catchments in Denmark and simulated lag times for nitrate transport between root zone and the streams. It was inferred that it will take about 15 years before effect of applying restrictions on fertilizer $\mathrm{N}$ use in the catchment area becomes visible in the nitrate-N load to streams. Several other measures to reduce leaching losses of fertilizer $\mathrm{N}$ from agricultural soils to control water pollution problems revolve around amount of fertilizer $\mathrm{N}$, time of application, source modification and proper coordination with soil and water management and these have been reviewed by Di and Cameron [24], Choudhury and Kennedy [143], Goulding et al. [144], Kay et al. [145] and Cameron et al. [146]. To evaluate the role of adopting knowledge-based $\mathrm{N}$ management strategies in achieving increased synchronization of crop $\mathrm{N}$ demand with $\mathrm{N}$ supply, Xia et al. [147] conducted a meta-analysis based on studies carried out in China on the application of controlled-release $\mathrm{N}$ fertilizer, nitrification and urease inhibitors, application of fertilizer $\mathrm{N}$ in frequent split doses, lower basal $\mathrm{N}$ proportion, deep placement of fertilizer $\mathrm{N}$, and soil test based optimal $\mathrm{N}$ rate. It was revealed that compared to traditional $\mathrm{N}$ management, the knowledge-based $\mathrm{N}$ practices significantly reduced nitrate- $\mathrm{N}$ leaching by $13.6-37.3 \%$ and losses of $\mathrm{N}$ through runoff by $15.5-45.0 \%$.

Cerro et al. [148] used the SWAT model to simulate land management options to reduce nitrate pollution in the Alegria watershed in northern Spain in which nitrate- $\mathrm{N}$ moves from the soil to the river through the alluvial aquifer. Farming activities cover $75 \%$ territory of the watershed and it is located in a nitrate-vulnerable zone. Best management practices recognized on the basis of local experience and interaction with farmers were evaluated for their long-term effects for a 50-year period. Results showed that reducing fertilizer $\mathrm{N}$ application by $20 \%$ will lead to a reduction of $50 \%$ of the number of days on which nitrate concentration will exceed the $50 \mathrm{mg} \mathrm{L}^{-1}$ limit. Haas et al. [149] studied the role of following the best management practices for crop production on leaching of nitrate$\mathrm{N}$ and used the SWAT model to evaluate environmental protection vis-à-vis economic considerations. Nangia et al. [150] calibrated and validated the Agricultural Drainage and Pesticide Transport (ADAPT) model to evaluate the effect of rate and time of application of fertilizer $\mathrm{N}$ on nitrate- $\mathrm{N}$ losses in commercial row crop fields located in south-central Minnesota in USA. It was predicted that by reducing fertilizer $\mathrm{N}$ application to crops in fall from 180 to $123 \mathrm{~kg} \mathrm{~N} \mathrm{ha}^{-1}$, loss of nitrate-N can be reduced by as much as $13 \%$. By switching fertilizer $\mathrm{N}$ application from fall to spring resulted in further $9 \%$ reduction in nitrate-N load to the Gulf of Mexico. Using the ADAPT model and working on poorly drained Webster clay loam soil (mesic Typic Haplaquols), Davis et al. [151] also found that by reducing fertilizer $\mathrm{N}$ application rate from 225 to $175 \mathrm{~kg} \mathrm{ha}^{-1}$ decreased nitrate losses by $48 \%$. Similarly, Baksh et al. [152] used the Walnut Creek watershed data with the Root Zone Water Quality Model (RZWQM) and found that reducing the fertilizer $\mathrm{N}$ application rate from 175 to $125 \mathrm{~kg} \mathrm{~N} \mathrm{ha}^{-1}$ resulted in a $22 \%$ decrease in nitrate-N losses. Peña-Haro et al. [153] successfully used a hydro-economic modelling framework to define the economically optimal allocation of spatially variable fertilizer standards in agricultural watersheds of an aquifer in Spain polluted with nitrate due to fertilizer use in irrigated crops. Using results from simulation of agronomic outputs and flow and transport of groundwater, the model provides a management framework to allocate fertilizer application in such a way that maximum economic benefits will be achieved while complying with environmental standards.

Biochar application to soils can reduce nitrate-N leaching because nitrates are indirectly attracted via electrostatic bridge bonding with divalent cations such as $\mathrm{Ca}^{2+}$ or $\mathrm{Mg}^{2+}$ and trivalent metals like $\mathrm{Al}^{3+}$ and $\mathrm{Fe}^{3+}$ to negatively charged carboxyl and phenolic hydroxyl groups on the biochar surface[154]. Also, due to its large surface area and high porosity, biochar application to the soil can 
reduce soil water percolation and the $\mathrm{N}$ contained in it [155]. Thus the meta-analysis based on 36 publications (156 observations) on soil $\mathrm{N}$ leaching as conducted by Liu et al. [156] revealed that biochar application to some soils significantly reduced nitrate-N leaching by $26 \%$. The extent of reduction increased with increasing biochar addition rate and in soils with low organic carbon content. Biochars produced under low pyrolysis temperature and those produced from wood rather than straw were more effective in reducing $\mathrm{N}$ leaching. Recently, Borchard et al. [157] conducted a meta-analysis which revealed that by applying biochar while concentration of nitrate- $\mathrm{N}$ in the soil was not influenced, its leaching was reduced by $13 \%$; average reduction in nitrate- $\mathrm{N}$ leaching was found to be $26 \%$ over the experimental times more than 30 days.

Many cash crop plantations such as tea established on hills and mountains are often located on the upper reaches of streams and rivers and heavy dressings of fertilizers ensure optimum production levels. Heavy rainfall events generally lead to substantial losses of $\mathrm{N}$ and $\mathrm{P}$ through leaching and runoff to surface and groundwater. A four-year study in the tea plantations in Danjiangkou Reservoir of China conducted by Liu et al. [158] revealed that when $\mathrm{N}$ and $\mathrm{P}$ were applied as drip fertigation rather than top dressing, losses of $\mathrm{N}$ and $\mathrm{P}$ through runoff and leaching to water bodies were reduced but not at the cost of production.

Structural adjustments in agriculture in terms of changes in land use patterns based on different crops and crop rotations can reduce environmental impacts of fertilizers including enrichments of water bodies with nutrients. Since $\mathrm{N}$ pollution is primarily governed by the intensity and extent of agricultural land use in a watershed $[88,108,109]$, Li et al. [87] reported that $\mathrm{N}$ exports from a Chinese subtropical watershed and total $\mathrm{N}$ loading to the river network was positively correlated with percentage of upland fields and negatively correlated with proportion of lowland paddy fields in the watershed area. Whereas upland cropping increases $\mathrm{N}$ loading to streams due to excessive anthropogenic inputs of $\mathrm{N}$ [110], lowland rice fields are associated with lower $\mathrm{N}$ export, due largely to a higher hydraulic retention time and anoxic conditions conducive to denitrification [159-161]. Thus inter-conversion of land use between low land rice and upland crops like wheat and maize can significantly change amount of applied $\mathrm{N}$ and associated $\mathrm{N}$ loss from the land to water bodies. Similarly, Min and Shi [162] reported that in a celery-tomato-fallow-lettuce rotation, $56 \%$ and $12 \%$ applied $\mathrm{N}$ was lost via leaching and runoff, respectively. However, including a leguminous crop in the rotation reduced annual $\mathrm{N}$ leaching by $36 \%$ without any economic impact. And in the lowland rice fields adjacent to the field under vegetable rotation, $\mathrm{N}$ loss via runoff was $73 \%$ less than in the vegetable fields. Recently, due to large scale importing of soybean to China and converting $\mathrm{N}$-fixing soybean fields to high $\mathrm{N}$-demanding crops like wheat, maize, rice, and vegetables resulted in increased $\mathrm{N}$ pollution in water bodies in China [163]. Although, differences in the environmental impacts of different crops is determined by contrasting $\mathrm{N}$ surpluses, $\mathrm{N}$ enrichment of water bodies can be controlled to certain extent by appropriate structural adjustments in agricultural land use.

Distributing $\mathrm{N}$ inputs across locations in order to maximize production for a given amount of total $\mathrm{N}$ input should also reduce $\mathrm{N}$ losses to the environment. This is a win-win approach. According to Mueller et al. [164], N lost to the environment could be mitigated by $41 \%$ through optimum or efficient $\mathrm{N}$ allocation between regions during 1961-2009. Also, global N surplus during 1994-2009 has become $69 \%$ greater than what could have been achieved with efficient $\mathrm{N}$ allocation between regions. Opportunities for spatial allocation can be realized on different scales such as between major world regions, continents, countries, within countries and across landscapes. Chinese farmers, for example, may be persuaded to apply less fertilizer $\mathrm{N}$ in their fields and that the amount saved will be used in sub-Saharan Africa or Latin America. Although no intergovernmental mechanism exits or even under consideration, interconnected global markets may provide some kind of mechanism to promote efficient $\mathrm{N}$ allocation for crop production [165]. Nevertheless, optimization of $\mathrm{N}$ allocation at sub-national or smaller scale seems practical. One of the major advantage of efficient reallocation of $\mathrm{N}$ is that no additional development or adoption of fertilizer management practices will be required [165].

Generally $\mathrm{P}$ alone is considered to promote harmful algal bloom formation in lakes so that reducing $P$ inputs is the often prescribed solution to avoid eutrophication. Paerl et al. [166] reviewed data from several whole-lake experiments in China, USA, Spain and Belgium and found that harmful algal bloom formation is stimulated more by combined enrichment of $\mathrm{N}$ and $\mathrm{P}$. Reduction in $\mathrm{P}$ input decreased harmful algal blume in many lakes, but not in others. By reducing input of both $\mathrm{N}$ and $\mathrm{P}, \mathrm{N}$ export to downstream $\mathrm{N}$-sensitive ecosystems was also reduced. Thus eutrophication along the freshwater-marine continuum can be effectively reduced by controlling the balanced between $\mathrm{N}$ and $\mathrm{P}$ inputs.

In some countries, improvement of educational standards of extension agents, increasing awareness and understanding of environmental costs due to fertilizer over-use, and voluntary codes of conduct on fertilizer use can help reduce extent of water pollution due to fertilizer use in agricultural crop production systems [136]. Ma et al. [167] reported that environmental awareness about the effect of fertilizer use on water pollution and a positive attitude to 
risk had an encouraging effect towards increasing fertilizer use efficiency in the Taihu Basin, China.

\section{Key issues for research}

From the perspective of individual farmers, nitrate pollution of surface and ground waters due to excessive use of $\mathrm{N}$ fertilizers can be viewed in terms of inefficient management of expensive inputs for crop production. But it is also an environmental issue that requires a group, community or even regional effort to resolve. Adding the complexities of the nutrient transformations and transport that allow the pinpointing of the nutrient source makes a good case for conservation programs that integrate regional and industry-based collaboration [168]. Research is needed on the design and implementation of novel conservation practices.

In the coming decades, agricultural production systems will have to produce more food and feed than ever before but using less land. Mueller et al. [169] advocate sustainable intensification, on the basis of which overuse of fertilizers could be eliminated without reducing food production. Nevertheless, intensive production systems will continue to rely on fertilizers to supply nutrients but are also likely to experience more frequent and more disruptions due to projected scenarios of global warming. Thus the challenges to understand and mitigate fertilizer related water quality issues are expected to be even more complex in the future. For example, extreme rainfall events associated with future climate change scenarios will increase the risk of downward movement up to ground water of the nitrate$\mathrm{N}$ accumulated in the soil profile below the root zone or in vadose zone. As reported by Zhou et al. [16], annual rainfall in Northern China has declined from $\sim 600 \mathrm{~mm}$ in 1960s to $\sim 500 \mathrm{~mm}$ in $2010 \mathrm{~s}$, but extreme rainfall events, particularly in summer have increased during this period. During each heavy rainfall event, both the newly formed nitrate- $\mathrm{N}$ and accumulated nitrate- $\mathrm{N}$ will be transported along with water to the vadose zone or shallow groundwater.

Work of Sebilo et al. [38] convincingly suggests that part of the fertilizer $\mathrm{N}$ applied to the soil today continues to be taken up by crops as well as leach toward the groundwater in the form of nitrate for at least another five decades, much longer than previously thought. Therefore reducing uncertainty in the amount of $\mathrm{N}$ that can be supplied by $\mathrm{N}$ mineralization is going to remain one of the biggest challenges in the years to come. In fact, this uncertainty is also one of the major obstacles in synchronizing fertilizer $\mathrm{N}$ application to meet $\mathrm{N}$ demand of the crop and determining optimum fertilizer $\mathrm{N}$ application rates. Thus one of the top priority future research needs is going to be the improvement in our quantitative understanding of $\mathrm{N}$ mineralization rate as influenced by soil, environmental and management practices.

By minimizing the accumulation of mineral $\mathrm{N}$ in the soil before water percolates down the profile, nitrate-N leaching from agroecosystems can be effectively reduced. It can be achieved through research focused on developing best fertilizer management practices before and during the crop growing season as well as post-harvest nutrient management in cropping systems. As potential for nitrate leaching differs between different crop production systems, there is a need to adopt an integrated approach in regional planning so as to balance the mix of various land use systems and optimize for different geographical locations. As reviewed by Liu et al. [156] and Borchard et al. [157], biochar can effectively reduce nitrate-N leaching from agricultural soils. Research on biochar-based $\mathrm{N}$ loss mitigation studies from the perspective of nitrate pollution of freshwaters needs to be strengthened in the years to come.

During last two decades, along with other agricultural practices, retention of crop residue on the soil surface, the use of cover crops during fallow period, and better synchronization between fertilizer application and crop $\mathrm{N}$ demand have also been evaluated with the aim of mitigating $\mathrm{N}$ loss from agroecosystems [170]. Collectively, these practices along with no-tillage are referred to as conservation agriculture which encompasses improved $\mathrm{N}$ management in cropping systems. However, its impact on water quality through nitrate- $\mathrm{N}$ leaching loss remains controversial. A meta-analysis conducted by Daryanto et al. [171] revealed that as compared to conventional tillage, conservation agriculture resulted in an overall increase of runoff nitrate- $\mathrm{N}$ concentration, but similar runoff nitrate$\mathrm{N}$ load. But nitrate- $\mathrm{N}$ load in the leachate was greater under conservation agriculture than under conventional tillage, although nitrate- $\mathrm{N}$ concentration in the leachate was similar under both tillage practices. It suggests that water flux was mainly responsible for determining nitrate$\mathrm{N}$ load. Some deviations from these overall trends were also recorded with different co-varying variables, but it is suggested that conservation agriculture be evaluated with other land management practices such as cover crops, reduced $\mathrm{N}$ rate, and split $\mathrm{N}$ application in terms of improving soil $\mathrm{N}$ retention and water quality benefits.

Nitrate- $\mathrm{N}$ being very soluble moves along with percolating water down to aquifers but $\mathrm{P}$ being less mobile and bound to soil particles reaches surface water bodies via erosion. These opposing pathways complicate the conservation of water quality because reducing one will intensify the other. Also, reducing the application level of one of the nutrients may result in unfavourable nutrient ratio in the soil and reduced uptake of nutrients by crop plants thereby not leading to reduction in the loss of the 
other nutrient. For example, low application levels of fertilizer $\mathrm{P}$ and $\mathrm{K}$ will limits the uptake of $\mathrm{N}$ by plants, which may result in increased loss of $\mathrm{N}$ from the soil-plant system to water bodies. According to Lawniczak et al. [172], an unfavourable nutrient ratio in the soil due potassium deficiency may affect two-thirds of the world's agricultural lands.

Nitrate leaching losses beyond rooting depth can be reduced by encouraging denitrification. Research is needed to ensure that this strategy does not lead to large emissions of nitrous oxide, which is a potent greenhouse and ozone depletion gas. Ideally, research efforts should be directed towards developing fertilizer best management practices which should reduce both nitrate leaching and nitrous oxide emissions. Using a source-pathway-receptor framework, a paradigmatic study on the impact of climate change on future nitrate- $\mathrm{N}$ concentrations in groundwater in UK provides an account of potential changes on the hydrological processes that will affect nitrate-N concentration [173].

Changes in rainfall pattern directly or indirectly affect the regional water resources, but altering rainfall patterns worldwide are the signature of global climate change. In general, wet areas become wetter, and dry and arid areas become more so [174]. Decreases in precipitation in the subtropics and tropics outside of the monsoon trough (especially in Mediterranean, southern Asia, and throughout Africa), and increases in land precipitation at higher latitudes, notably over North America, Eurasia, and Argentina have been observed [175]. Climate-change is also resulting in extreme rainfall events, which may lead to increased risk of accumulated nitrate-N moving downwards and polluting the groundwater. Because leaching of nitrate- $\mathrm{N}$ depends not only on the total amount of annual precipitation but also the intensity of rainfall, in a study conducted by Zhou et al. [16] in North China Plain, it was observed that due to two heavy rainfall events (> $70 \mathrm{~mm}$ ) nitrate accumulation increased from 1068 \pm 190 to $1583 \pm 319 \mathrm{~kg} \mathrm{~N} \mathrm{ha}^{-1}$ and the peak of nitrate accumulation moved downward $120 \mathrm{~cm}$. On the other hand, in many regions on Earth, when climate change is likely to bring a shift towards drier conditions, a diminution of the aquifer dilution capacity is the consequence. Because aspects of global change are characterised by both climate and human pressures, the persistence of nitrate in groundwater needs to be examined by taking into account all the processes that, once influenced by global climatic change, would change the pattern of nitrate concentrations and that of groundwater quality [176].

During the last more than two decades, enhanced efficiency fertilizers like polymer coated fertilizers, nitrification inhibitors, urease inhibitors and double inhibitors (nitrification and urease inhibitors combined) have been developed to improve synchrony between fertilizer $\mathrm{N}$ release and $\mathrm{N}$ uptake pattern of the crops to enhance fertilizer $\mathrm{N}$ use efficiency and reduce losses of $\mathrm{N}$ from the soil-plant system. Using a meta-analysis based on 203 research papers from 18 countries published between 1980 and 2016, Li et al. [177] concluded that while both productivity and environmental efficacy were governed by the combination of enhanced efficiency fertilizer, cropping system and biophysical conditions, on an overall basis the double inhibitors used in grassland could reduce $\mathrm{N}$ loss by $47 \%$ and urease inhibitors used in lowland rice resulted in $\mathrm{N}$-loss reduction to the tune of $41 \%$. In maize and wheat, these fertilizers were generally less effective. The metaanalysis further revealed that the enhanced efficiency fertilizers play a significant role by minimizing fertilizer mismanagement.

In 2015, China introduced improved fertilizer $\mathrm{N}$ management in field crops to achieve zero growth in chemical fertilizer use so as to reduce negative environmental impacts of $\mathrm{N}$ fertilizers while maintaining agricultural productivity [178]. Yu et al. [179] used DNDC model to show that improved $\mathrm{N}$ management practices such as applying the right fertilizer products at the right rate, at the right time and in the right place and use of controlled release fertilizers could reduce $\mathrm{N}$ discharge from cropland from $5.1 \pm 0.3$ to $2.8-3.0 \mathrm{Mt} \mathrm{N}$ year ${ }^{-1}$. Cui et al. [180] estimated that if all the smallholder farmers could adopt the improved $\mathrm{N}$ management practices, excess $\mathrm{N}$ discharge from cropped soils will be reduced by $23-25 \%$.

Many stewardship measures for reducing leaching of nitrate-N have been developed for terrestrial ecology gain rather than from a water quality perspective. Sufficient and relevant information is not available on quantifying the impacts of such stewardship measures on water quality. Only a few studies have been undertaken to quantify the impact of agricultural stewardship measures at the catchment scale. As most of the available research information has been generated on the plot and field scale, there is urgent need of further research, particularly on catchment scale [145]. Another aspect of implementing stewardship measures for reducing nitrate-N leaching is that if new initiatives are not applied in the entire catchment, it is likely that gains from the new management may get negated by where the stewardship measures are not followed. Also, while studying impacts of agricultural stewardship measures on water quality impacts on farm incomes should not ignored. Despite significant scientific evidence to use several agri-environment measures, these may not find favour with farmers and agribusinesses due to lack of steadfast decisions based on sound economics.

There is need to develop management-oriented decision support systems to formulate best practices for achieving optimum production and minimal leaching of 
nitrate from agro-ecosystems. The data generated from many countries and regions on different aspects $\mathrm{N}$ cycling, nitrate leaching and response of different crops to fertilizer $\mathrm{N}$ should be collated and used to develop new models or to improve the existing models. Decision support systems that link models of $\mathrm{N}$ dynamics in soil-plant system, nitrate leaching, plant growth and modern diagnostic tools to estimate fertilizer $\mathrm{N}$ requirement of different crops may be able to generate required fertilizer management scenarios.

Improved information about fertilizer impacts on water quality is the key to sound evidence-based approaches to environmental policies and actions that address the problem. A broad range of emerging information technologies provide opportunities for monitoring and managing water pollution by fertilizers as well as many other aspects of agricultural production. At the global, national and watershed levels, big data technology promises to provide a basis for capturing, storing and analysing current unstructured information on fertilizer application rates and water pollution [181, 182]. Precision agriculture exacerbates the big data problem as the data flow from sensors such as yield monitors, portable devices, drones, and smart phones has increased dramatically over the last decade. Using high resolution satellite imagery, Basso et al. [183] estimated $N$ use efficiency in corn fields over a 30 million ha area in USA. Efficiency was only $48 \%$ in the stable low yield areas but was as high as $88 \%$ in stable high yield areas. Reducing fertilizer rates in the low yield stability areas would reduce environmental impacts with no significant effects on yield. Spatial dimensions have been incorporated into a GIS-based decision support framework designed by Chowdary et al. [184]. The framework can be used for the assessment of non-point-source pollution of groundwater in large irrigation projects. Pathak et al. [185] reviewed some of the decision support systems in use in Asian countries and pointed out how their widespread adoption will lead to improved fertilizer management and reduced water pollution. No doubt with the rapid progress of even more sophisticated machine learning and artificial intelligence technologies, as developed in the USA, their application to precision farming will make major contributions towards the same goal [186].

In the last decade, regional and global model intercomparison projects have been used as a framework to evaluate and compare models, and associated model input, structural, and parameter uncertainty to achieve different objectives [187]. Water quality model inter-comparison projects on nitrate pollution of natural water bodies should facilitate the development of harmonized data estimates of current and future water quality, and improve understanding of processes as well as model uncertainties. While mechanistic and process-based basin and local scale water quality models rely upon experimental approaches in simplified manner, global water quality models on nitrate enrichment constitute another emerging field because these can account for large-scale drivers that are difficult to capture in basin-scale models and can elucidate the interplays among drivers such as climate change and virtual water and pollution transfer related to international trade [188]. As nitrate pollution of water bodies is increasingly becoming a global concern, assessments using global water quality modelling are needed to identify hotspots and trends, especially in regions where data is insufficient for a detailed assessment.

\section{Conclusions}

With the continuous expansion in fertilizer $\mathrm{N}$ use in agriculture, nitrate pollution of natural water bodies and its possible remediation are being aggressively studied in major agro-production regions of the world. The researches carried out all over the world, primarily during the last two decades, have been reviewed. Conclusions drawn in terms increased understanding of the problem, tools and methods used to measure the extent of nitrate pollution of natural water bodies due to fertilizer use, possible remedial measures to reduce the contribution of fertilizers to nitrate leaching and what more needs to be done are listed below.

- Fertilizer $\mathrm{N}$ effects on freshwater quality are relatively localised even at the basin scale. Although fertilizer management is the domain of individual farmers, consumption pattern of fertilizer $\mathrm{N}$ at region or country level provides the first hand information about the possibility of nitrate-N pollution in water bodies. Prior to 1980s, fertilizer $\mathrm{N}$ consumption was greater in industrialized nations in North America and Europe than in most of the developing countries. However the trend has reversed after 1990 so that nitrate pollution of freshwaters due to fertilizer use is now visible and being studied intensively even in developing countries, particularly in East and South Asia.

- How and in what proportion of nitrate-N originating from fertilizer $\mathrm{N}$ applied to agricultural crops reaches surface and ground waters continues to remain an important issue although better estimates are now becoming available. Recent studies show that the proportion of fertilizer $\mathrm{N}$ applied to agroecosystems leaching below the rooting zone is less than the $30 \%$, which is the fixed soil nitrate leaching emission factor used by the Intergovernmental Panel on Climate Change. Until and unless organic manures are applied in sufficient quantities and on a long-term basis, losses of nitrate$\mathrm{N}$ from agricultural fields amended with manures are 
generally lower than when $\mathrm{N}$ is applied through mineral fertilizers.

- Field crops do not use more than $50 \%$ of the applied $\mathrm{N}$, but depending upon soil, climate and management factors, only a small portion is lost through different mechanisms including leaching as nitrate from the soil-plant system. A substantial portion of the applied $\mathrm{N}$ becomes a part of the large pool of organically bound $\mathrm{N}$ in the soil. Management strategies such as optimization of fertilizer $\mathrm{N}$ rates may lead to rapid reductions in nitrate leaching from agricultural systems, but the present trends of nitrate pollution of freshwaters also reflect legacies of current and past applications of fertilizers and manures during last several decades.

- Nitrogen fertilizers applied to agroecosystems are not the only source of nitrate- $\mathrm{N}$ in water bodies. Substantial amount of nitrate- $\mathrm{N}$ generated from soil organic matter, organic manures, city sewage and animal excreta can also reach the freshwaters. In recent decades, natural variations in stable isotopes of $\mathrm{N}$ and $\mathrm{O}$ in nitrates have been used for identifying the contribution of mineral fertilizers, organic manures and soil $\mathrm{N}$ in nitrate- $\mathrm{N}$ accumulation in surface and ground water bodies.

- Simulation models are increasingly being used as efficient tools for predicting and managing nitrate- $\mathrm{N}$ pollution of surface and ground waters. Although several models have been developed with a focus either on nitrate leaching in the root zone or on transformations and movement of nitrate- $\mathrm{N}$ in the unsaturated zone, these have also been used to study the impacts of fertilizer management (rate, time of application, source), precipitation pattern, irrigation strategies, and soil types on nitrate-N leaching in soils. More recently, conceptual models integrating different components of the nitrate movement pathway or frameworks connecting spatially-distributed and process-based watershed models are being used.

- Nitrate-N enrichment of groundwater has been widely researched as diffuse pollution since extensive use of $\mathrm{N}$ fertilizers was introduced for crop production. In recent decades, eutrophication of lakes, reservoirs, ponds and coastal water bodies due to enrichment with $\mathrm{N}$ and increasing $\mathrm{N}$ concentration in rivers all over the world along with continuously increasing use of $\mathrm{N}$ fertilizers even in developing countries, surface water pollution as linked with fertilizers is also receiving increasing attention of researchers from disciplines of soil science, hydrology and simulation modelling.

- Improvement in water management had the largest effect on reducing nitrate- $\mathrm{N}$ leaching from agroecosystems to which fertilizer $\mathrm{N}$ is applied for crop pro- duction. It was followed by improved fertilizer management and improvement in fertilizer technologies.

- Among fertilizer management strategies, application of optimum fertilizer $\mathrm{N}$ rates is the most effective for controlling leakage of nitrate- $\mathrm{N}$ from the soil-plant system. Adjusting the time of application of fertilizer $\mathrm{N}$ to mirror the $\mathrm{N}$ uptake pattern of crops can lead to reduced nitrate- $\mathrm{N}$ leaching beyond rooting zone of crops. Simulation models for nitrate enrichment of aquifers and surface water bodies also show reduction in nitrate pollution with optimal allocation of spatially variable fertilizer standards in agricultural watersheds. This is a knowledge intensive approach which may in practice be offset by practical factors such as the relatively high real and opportunity costs of farm labour.

- Strategies like structural adjustments in agriculture in terms of changes in land use patterns based on different crops and crop rotations, use of biochar and distributing $\mathrm{N}$ inputs across locations to maximize production show promise for reducing leaching loss of nitrate-N. Improvement in educational standards of extension agents, increasing awareness and understanding of environmental costs caused by fertilizer over-use may also help in controlling fertilizer related nitrate pollution of freshwaters.

- Some of the issues that need the attention of future researchers include: the role of future climate change scenarios related extreme rainfall events and potential changes on the hydrological processes; improved quantitative understanding of $\mathrm{N}$ mineralization; the effects of conservation agriculture practices; the development of enhanced efficiency fertilizers; quantifying the impact of agricultural stewardship measures on catchment scale; and the use of information technologies for monitoring and managing water pollution from application of fertilizer $\mathrm{N}$ in crop production.

\section{Declarations}

Conflict of interest The authors declare no conflicts of interest.

Open Access This article is licensed under a Creative Commons Attribution 4.0 International License, which permits use, sharing, adaptation, distribution and reproduction in any medium or format, as long as you give appropriate credit to the original author(s) and the source, provide a link to the Creative Commons licence, and indicate if changes were made. The images or other third party material in this article are included in the article's Creative Commons licence, unless indicated otherwise in a credit line to the material. If material is not included in the article's Creative Commons licence and your intended use is not permitted by statutory regulation or exceeds the permitted 
use, you will need to obtain permission directly from the copyright holder. To view a copy of this licence, visit http://creativecommons. org/licenses/by/4.0/.

\section{References}

1. Bartley R, Henderson A, Prosser IP, Hughes AO, McKergow LA, Lu H, Brodie J, Bainbridge Z, Roth CH (2003) Patterns of erosion and sediment and nutrient transport in the Herbert River catchment, Queensland. Consultancy Report. August 2003, CSIRO Land and Water, p 59

2. Howarth RW (2008) Coastal nitrogen pollution: a review of sources and trends globally and regionally. Harmful Algae 8:14-20. https://doi.org/10.1016/j.hal.2008.08.015

3. Glibert PM, Harrison J, Heil C, Seitzinger S (2006) Escalating worldwide use of urea-a global change contributing to coastal eutrophication. Biogeochem 77:441-463. https://doi. org/10.1007/s10533-005-3070-5

4. Zadeh SM (2018) Nutrients. In: Mateo-Sagasta J, Zadeh SM, Turral H (eds), More people, more food, worse water?: A global review of water pollution from agriculture. Food and Agriculture Organization of UNO, Rome, Italy; International Water Management Institute (IWMI), CGIAR Research Program on Water, Land and Ecosystems (WLE), Colombo, Sri Lanka. pp 53-75. http://www.fao.org/3/ca0146en/CA0146EN.pdf

5. Shukla S, Saxena A (2018) Global status of nitrate contamination in groundwater: its occurrence, health impacts, and mitigation measures. In: Hussain CM (ed) Handbook of environmental materials management. Springer, pp 869-888. https:// doi.org/10.1007/978-3-319-58538-3_20-1

6. Ji Y, Liu H, Shi Y (2020) Will China's fertilizer use continue to decline? Evidence from LMDI analysis based on crops, regions and fertilizer types. PLoS ONE 15(8):e0237234. https://doi.org/ 10.1371/journal.pone.0237234

7. Liu J, You L, Amini M, Obersteiner M, Herrero M, Zehnder AJB, Yang $\mathrm{H}$ (2010) A high-resolution assessment on global nitrogen flows in cropland. Proc Natl Acad Sci USA 107:8035-8040. https://doi.org/10.1073/pnas.0913658107

8. Zhang X, Xu Z, Sun X, Dong W, Ballantine D (2013) Nitrate in shallow groundwater in typical agricultural and forest ecosystems in China, 2004-2010. J Environ Sci 25:1007-1014. https:// doi.org/10.1016/S1001-0742(12)60139-9

9. Howarth RW, Billen G, Swaney D, Townsend A, Jaworski N, Lajtha K, Downing JA, Elmgren R, Caraco N, Jordan T, Berendse F, Freney J, Kudeyarov V, Murdoch P, Zhao-Liang Z (1996) Regional nitrogen budgets and riverine $N$ \& $P$ fluxes for the drainages to the North Atlantic Ocean: Natural and human influences. In: Howarth RW (ed), Nitrogen cycling in the North Atlantic Ocean and its watersheds, Springer, Dordrecht, pp 75-139. https://doi.org/10.1007/978-94-009-1776-7_3

10. Donoso G, Cancino J, Magri A (1999) Effects of agricultural activities on water pollution with nitrates and pesticides in the Central Valley of Chile. Water Sci Technol 39:49-60. https://doi. org/10.1016/S0273-1223(99)00031-1

11. Liu GD, Wu WL, Zhang J (2005) Regional differentiation of nonpoint source pollution of agriculture-derived nitrate nitrogen in groundwater in northern China. Agri Ecosyst Environ 107:211-220. https://doi.org/10.1016/j.agee.2004.11.010

12. Galloway JN, Dentener FJ, Capone DG, Boyer EW, Howarth RW, Seitzinger SP, Asner GP, Cleveland CC, Green PA, Holland EA, Karl DM (2004) Nitrogen cycles: past, present, and future. Biogeochem 70:153-226. https://doi.org/10.1007/ s10533-004-0370-0
13. Galloway JN, Aber JD, Erisman JW, Seitzinger SP, Howarth RW, Cowling EB, Cosby BJ (2003) The nitrogen cascade . BioScience 53:341-356. https://doi.org/10.1641/0006-3568(2003) 053[0341:TNC]2.0.CO;2

14. Meisinger JJ, Delgado JA, Alva AK (2006) Nitrogen leaching management. Encyclop Soils Environ 2:1122-1124

15. Ju XT, Zhang C (2017) Nitrogen cycling and environmental impacts in upland agricultural soils in North China: a review. $J$ Integr Agric 16:2848-2862. https://doi.org/10.1016/S20953119(17)61743-X

16. Zhou JY, Gu BJ, Schlesinger WH, Ju XT (2016) Significant accumulation of nitrate in Chinese semi-humid croplands. Sci Rep 6:25088. https://doi.org/10.1038/srep25088

17. Ju XT, Kou CL, Zhang FS, Christie P (2006) Nitrogen balance and groundwater nitrate contamination: comparison among three intensive cropping systems on the North China Plain. Environ Pollut 143:117-125. https://doi.org/10.1016/j.envpol.2005.11. 005

18. Zhao RF, Chen XP, Zhang FS, Zhang HL, Schroder J, Romheld $V$ (2006) Fertilization and nitrogen balance in a wheat-maize rotation system in North China. Agron J 98:938-945. https:// doi.org/10.2134/agronj2005.0157

19. Huang $T$, Ju XT, Yang $H$ (2017) Nitrate leaching in a winter wheat-summer maize rotation on a calcareous soil as affected by nitrogen and straw management. Sci Rep 7:42247. https:// doi.org/10.1038/srep42247

20. Jankowski K, Neill C, Davidson EA, Macedo MN, Costa C, Galford GL, Santos LM, Lefebvre P, Nunes D, Cerri CE, McHorney R (2018) Deep soils modify environmental consequences of increased nitrogen fertilizer use in intensifying Amazon agriculture. Sci Rep 8:13478. https://doi.org/10.1038/s41598-018-31175-1

21. Zhou M, Butterbach-Bahl K (2014) Assessment of nitrate leaching loss on a yield-scaled basis from maize and wheat cropping systems. Plant Soil 374:977-991. https://doi.org/10.1007/ s11104-013-1876-9

22. Goulding KWT, Poulton PR, Webster CP, Howe MT (2000) Nitrate leaching from the Broadbalk Wheat Experiment, Rothamsted, UK, as influenced by fertilizer and manure inputs and the weather. Soil Use Manag 16:244-250. https://doi.org/10.1111/j. 1475-2743.2000.tb00203.x

23. Wang $Y$, Ying $H$, Yin $Y$, Zheng $H, C$ Cui $Z$ (2019) Estimating soil nitrate leaching of nitrogen fertilizer from global meta-analysis. Sci Total Environ 657:96-102. https://doi.org/10.1016/j.scito tenv.2018.12.029

24. Di HJ, Cameron KC (2002) Nitrate leaching in temperate agroecosystems: sources, factors and mitigating strategies. Nutr Cycl Agroecosyst 64:237-256. https://doi.org/10.1023/A:10214 71531188

25. Powlson DS, Poulton PR, Addiscott TM, McCann DS (1989) Leaching of nitrate from soils receiving organic or inorganic fertilizers continuously for 135 years. In: Hansen JAA, Henriksen $\mathrm{K}$ (eds) Nitrogen in organic wastes applied to soils. Academic Press, London, pp 334-345

26. Preetha PP, Al-Hamdan AZ (2020) Developing nitrate-nitrogen transport models using remotely-sensed geospatial data of soil moisture profiles and wet depositions. J Environ Sci Health Part A 55:615-628. https://doi.org/10.1080/10934529.2020.17245 03

27. Bijay-Singh, Sekhon GS (1979) Nitrate pollution of groundwater from farm use of nitrogen fertilizers-a review. Agric Environ $4: 207-225$

28. Zhao BQ, Li XY, Liu H, Wang BR, Zhu P, Huang $S M$, Bao DJ, Li $Y T$, So HB (2011) Results from long-term fertilizer experiments in China: the risk of groundwater pollution by nitrate. 
NJAS-Wagening J Life Sci 58:177-183. https://doi.org/10. 1016/j.njas.2011.09.004

29. Chien SH, Prochnow LI, Cantarella H, Donald LS (2009) Recent developments of fertilizer production and use to improve nutrient efficiency and minimize environmental impacts. Adv Agron 102:267-322. https://doi.org/10.1016/S0065-2113(09) 01008-6

30. Ladha JK, Pathak H, Krupnik TJ, Six J, van Kessel C (2005) Efficiency of fertilizer nitrogen in cereal production: retrospects and prospects. Adv Agron 87:85-156. https://doi.org/10.1016/ S0065-2113(05)87003-8

31. Hart PBS, Powlson DS, Pulton PR, Johnson AE, Jenkinson DS (1993) The availability of the nitrogen in the crop residues of winter wheat to subsequent crops. J Agric Sci 121:355-362. https://doi.org/10.1017/S0021859600085555

32. IAEA (International Atomic, Energy Agency) (2003) Management of crop residues for sustainable crop production. IAEA TECHDOC-1354. International Atomic, Energy Agency, Vienna, Austria

33. Kumar K, Goh KM (2002) Recovery of ${ }^{15} \mathrm{~N}$ labeled fertilizer applied to winter wheat and perennial ryegrass crops and residual ${ }^{15} \mathrm{~N}$ recovery by succeeding wheat crops under different crop residue management practices. Nutr Cycl Agroecosyst 62:123-130. https://doi.org/10.1023/A:1015595202542

34. Dourado-Neto D, Powlson D, Abu Bakar R, Bacchi OOS, Basanta MV, Thi Cong P, Keerthisinghe G, Ismaili M, Rahman SM, Reichardt K, Safwat MSA, Sangakkara R, Timm LC, Wang JY, Zagal $E$, van Kessel C (2010) Multiseason recoveries of organic and inorganic nitrogen-15 in tropical cropping systems. Soil Sci Soc Am J 74:139-152. https://doi.org/10.2136/sssaj2009.0192

35. Gardner JB, Drinkwater LE (2009) The fate of nitrogen in grain cropping systems: a meta-analysis of ${ }^{15} \mathrm{~N}$ field experiments. Ecol App 19:2167-2184. https://doi.org/10.1890/08-1122.1

36. Christensen BT (2004) Tightening the nitrogen cycle. In: Schjønning P, Elmholt S, Christensen BT (eds) Managing soil quality: challenges in modern agriculture. CABI Publishing, Oxon, pp 47-67

37. Goulding K (2000) Nitrate leaching from arable and horticultural land. Soil Use Manag 16:145-151. https://doi.org/10. 1111/j.1475-2743.2000.tb00218.x

38. Sebilo M, Mayer B, Nicolardot B, Pinay G, Mariotti A (2013) Longterm fate of nitrate fertilizer in agricultural soils. Proc Natl Acad Sci USA 110:18185-18189. https://doi.org/10.1073/pnas.13053 72110

39. Castellano MJ, David MB (2014) Long-term fate of nitrate fertilizer in agricultural soils is not necessarily related to nitrate leaching from agricultural soils. Proc Natl Acad Sci 111:E766E766. https://doi.org/10.1073/pnas.1321350111

40. Van Meter KJ, Basu NB, Veenstra JJ, Burras CL (2016) The nitrogen legacy: emerging evidence of nitrogen accumulation in anthropogenic landscapes. Environ Res Lett 11(3):035014. https://doi.org/10.1088/1748-9326/11/3/035014

41. Robinson $D(2001) \delta^{15} \mathrm{~N}$ as an integrator of the nitrogen cycle. Trends Ecol Evol 16:153-162. https://doi.org/10.1016/S01695347(00)02098-X

42. Choi WJ, Lee SM, Ro HM (2003) Evaluation of contamination sources of groundwater $\mathrm{NO}_{3}^{-}$using nitrogen isotope data: a review. Geosci J 7:81-87. https://doi.org/10.1007/BF02910268

43. Choi WJ, Han GH, Ro HM, Yoo SH, Lee SM (2002) Evaluation of nitrate contamination sources of unconfined groundwater in the North Han River basin of Korea using nitrogen isotope ratios. Geosci J 6:47-55. https://doi.org/10.1007/BF02911335

44. Zhang Y, Shi P, Song J, Li Q (2019) Application of nitrogen and oxygen isotopes for source and fate identification of nitrate pollution in surface water: a review. App Sci 9(1):18. https:// doi.org/10.3390/app9010018
45. Kendall C (1998) Tracing nitrogen sources and cycling in catchments. In: Kendall C, McDonnell JJ (eds) Isotope tracers in catchment hydrology. Elsevier, Amsterdam, pp 519-576

46. Li SL, Liu CQ, Lang YC, Zhao ZQ, Zhou ZH (2010) Tracing the sources of nitrate in karstic groundwater in Zunyi, Southwest China: a combined nitrogen isotope and water chemistry approach. Environ Earth Sci 60:1415-1423. https://doi.org/10. 1007/s12665-009-0277-0

47. Bateman AS, Kelly SD (2007) Fertilizer nitrogen isotope signatures. Isotopes Environ Health Stud 43:237-247. https://doi. org/10.1080/10256010701550732

48. Ding J, Xi B, Gao R, He L, Liu H, Dai X, Yu Y (2014) Identifying diffused nitrate sources in a stream in an agricultural field using a dual isotopic approach. Sci Total Environ 484:10-18. https:// doi.org/10.1016/j.scitotenv.2014.03.018

49. Zhang Y, Shi P, Li F, Wei A, Song J, Ma J (2018) Quantification of nitrate sources and fates in rivers in an irrigated agricultural area using environmental isotopes and a Bayesian isotope mixing model. Chemosphere 208:493-501. https://doi.org/ 10.1016/j.chemosphere.2018.05.164

50. Liu T, Wang F, Michalski G, Xia X, Liu S (2013) Using ${ }^{15} \mathrm{~N},{ }^{17} \mathrm{O}$, and ${ }^{18} \mathrm{O}$ to determine nitrate sources in the Yellow River, China. Environ Sci Tech 47:13412-13421. https://doi.org/10.1021/ es403357m

51. Yue FJ, Liu CQ, Li SL, Zhao ZQ, Liu XL, Ding H, Liu BJ, Zhong J (2014) Analysis of $\delta^{15} \mathrm{~N}$ and $\delta^{18} \mathrm{O}$ to identify nitrate sources and transformations in Songhua River, Northeast China. J Hydrol 519:329-339. https://doi.org/10.1016/j.jhydrol.2014.07.026

52. Soto DX, Koehler G, Wassenaar LI, Hobson KA (2019) Spatiotemporal variation of nitrate sources to Lake Winnipeg using $\mathrm{N}$ and $O$ isotope $\left(\delta^{15} \mathrm{~N}, \delta^{18} \mathrm{O}\right)$ analyses. Sci Total Environ 647:486493. https://doi.org/10.1016/j.scitotenv.2018.07.346

53. Urresti-Estala B, Vadillo-Perez I, Jimenez-Gavilan P, Soler A, Sanchez-Garcia D, Carrasco-Cantos F (2015) Application of stable isotopes $\left(\delta^{34} \mathrm{~S}_{-} \mathrm{SO}_{4}, \delta^{18} \mathrm{O}-\mathrm{SO}_{4}, \delta^{15} \mathrm{~N}-\mathrm{NO}_{3}, \delta^{18} \mathrm{O}-\mathrm{NO}_{3}\right)$ to determine natural background and contamination sources in the Guadalhorce River Basin (southern Spain). Sci Total Environ 506:46-57. https://doi.org/10.1016/j.scitotenv.2014.10.090

54. Wexler SK, Hiscock KM, Dennis PF (2009) Tracing the sources and fate of diffuse nitrate contamination in a lowland agricultural catchment using a dual-isotope method. European Geosciences Union General Assembly, p 691

55. Jin Z, Zheng Q, Zhu C, Wang Y, Cen J, Li F (2018) Contribution of nitrate sources in surface water in multiple land use areas by combining isotopes and a Bayesian isotope mixing model. App Geochem 93:10-19. https://doi.org/10.1016/j.apgeochem. 2018.03.014

56. Kim H, Kaown D, Mayer B, Lee JY, Hyun Y, Lee KK (2015) Identifying the sources of nitrate contamination of groundwater in an agricultural area (Haean basin, Korea) using isotope and microbial community analyses. Sci Total Environ 533:566-575. https://doi.org/10.1016/j.scitotenv.2015.06.080

57. Zhang Y, Li F, Zhang Q, Li J, Liu Q (2014) Tracing nitrate pollution sources and transformation in surface-and ground-waters using environmental isotopes. Sci Total Environ 490:213-222. https://doi.org/10.1016/j.scitotenv.2014.05.004

58. Nakamura K, Harter T, Hirono $Y$, Horino H, Mitsuno T (2004) Assessment of root zone nitrogen leaching as affected by irrigation and nutrient management practices. Vadose Zone J 3:1353-1366. https://doi.org/10.2136/vzj2004.1353

59. Gärdenäs Al, Hopmans JW, Hanson BR, Šimůnek J (2005) Twodimensional modeling of nitrate leaching for various fertigation scenarios under micro-irrigation. Agric Water Manag 74:219-242. https://doi.org/10.1016/j.agwat.2004.11.011

60. Hanson BR, Šimůnek J, Hopmans JW (2006) Evaluation of urea-ammoniumnitrate fertigation with drip irrigation using 
numerical modeling. Agri Water Manag 86:102-113. https:// doi.org/10.1016/j.agwat.2006.06.013

61. Tafteh A, Sepaskhah AR (2012) Application of HYDRUS-1D model for simulating water and nitrate leaching from continuous and alternate furrow irrigated rapeseed and maize fields. Agric Water Manag 113:19-29. https://doi.org/10.1016/j.agwat. 2012.06.011

62. Deb SK, Sharma P, Shukla MK, Ashigh J, Šimůnek J (2015) Numerical evaluation of nitrate distributions in the onion root zone under conventional furrow fertigation. J Hydrol Eng 21(2):05015026. https://doi.org/10.1061/(ASCE)HE.1943-5584. 0001304

63. MacQuarrie KTB, Sudicky EA, Robertson WD (2001) Numerical simulation of a fine-grained denitrification layer for removing septic system nitrate from shallow groundwater. J Contam Hydrol 52:29-55. https://doi.org/10.1016/S0169-7722(01) 00152-8

64. Lee MS, Lee KK, Hyun Y, Clement TP, Hamilton D (2006) Nitrogen transformation and transport modeling in groundwater aquifers. Ecol Model 192:143-159. https://doi.org/10.1016/j. ecolmodel.2005.07.013

65. Ledoux E, Gomez E, Monget JM, Viavattene C, Viennot $P$, Ducharne A, Benoît M, Mignolet C, Schott C, Mary B (2007) Agriculture and groundwater nitrate contamination in the Seine basin. The STICS-MODCOU modelling chain. Sci Total Environ 375:33-47. https://doi.org/10.1016/j.scitotenv.2006. 12.002

66. Poch-Massegú JR, Jiménez-Martínez J, Wallis KJ, Ramírez de Cartagena F, Candela L (2014) Irrigation return flow and nitrate leaching under different crops and irrigation methods in Western Mediterranean weather conditions. Agric Water Manag 134:1-13. https://doi.org/10.1016/j.agwat.2013.11.017

67. Plaza-bonilla D, Nolot J, Raffaillac D, Justes E (2015) Cover crops mitigate nitrate leaching in cropping systems including grain legumes: field evidence and model simulations. Agric Ecosyst Environ 212:1-12. https://doi.org/10.1016/j.agee.2015.06.014

68. Ma L, Scott HD, Shaffer MJ, Ahuja LR (1998) RZWQM simulations of water and nitrate movement in a manured tall fescue field. Soil Sci 163:259-270

69. Keating BA, Carberry PS, Hammer GL, Probert ME, Robertson MJ, Holzworth D, Huth NI, Hargreaves JN, Meinke H, Hochman Z, McLean G (2003) An overview of APSIM, a model designed for farming systems simulation. Eur J Agron 18:267-288. https://doi.org/10.1016/S1161-0301(02)00108-9

70. Stöckle CO, Donatelli M, Nelson R (2003) CropSyst, a cropping systems simulation model. Eur J Agron 18:289-307. https://doi. org/10.1016/S1161-0301(02)00109-0

71. van der Laan M, Annandale JG, Bristow KL, Stirzaker RJ, Du Preez CC, Thorburn PJ (2014) Modelling nitrogen leaching: are we getting the right answer for the right reason? Agric Water Manag 133:74-80. https://doi.org/10.1016/j.agwat.2013.10.017

72. Gassman PW, Reyes MR, Green CH, Arnold JG (2007) The soil and water assessment tool: Historical development, applications, and future research directions. Trans Am Soc Agri Biol Eng 50:1211-1250. https://doi.org/10.13031/2013.23637

73. Akbariyeh S, Bartelt-Hunt S, Snow D, Li X, Tang Z, Li Y (2018) Three-dimensional modeling of nitrate- $\mathrm{N}$ transport in vadose zone: roles of soil heterogeneity and groundwater flux. J Contam Hydrol 211:15-25. https://doi.org/10.1016/j.jconhyd.2018. 02.005

74. Hassan G, Reneau RB, Hagedorn C, Jantrania AR (2008) Modeling effluent distribution and nitrate transport through an onsite wastewater system. J Environ Qual 37:1937-1948. https:// doi.org/10.2134/jeq2007.0512

75. Hu K, Li B, Chen D, Zhang Y, Edis R (2008) Simulation of nitrate leaching under irrigated maize on sandy soil in desert oasis in Inner Mongolia, China. Agric Water Manag 95:1180-1188. https://doi.org/10.1016/j.agwat.2008.05.001

76. Ramos TB, Šimůnek J, Gonçalves MC, Martins JC, Prazeres A, Pereira LS (2012) Two-dimensional modeling of water and nitrogen fate from sweet sorghum irrigated with fresh and blended saline waters. Agric Water Manag 111:87-104. https:// doi.org/10.1016/j.agwat.2012.05.007

77. Wang Z, Li J, Li Y (2014) Simulation of nitrate leaching under varying drip system uniformities and precipitation patterns during the growing season of maize in the North China plain. Agric Water Manag 142:19-28

78. Baram S, Couvreur V, Harter T, Read M, Brown PH, Kandelous M, Smart DR, Hopmans JW (2017) Estimating nitrate leaching to groundwater from Orchards: comparing crop nitrogen excess, deep vadose zone data-driven estimates, and HYDRUS modeling. Vadose Zone J 15(11):1-13. https://doi.org/10.2136/vzj20 16.07.0061

79. Refsgaard JC, Thorsen M, Jensen JB, Kleeschulte S, Hansen S (1999) Large scale modeling of groundwater contamination from nitrate leaching. J Hydrol 221:117-140. https://doi.org/ 10.1016/S0022-1694(99)00081-5

80. Lasserre F, Razack M, Banton O (1999) A GIS-linked model for the assessment of nitrate contamination in groundwater. J Hydrol 224:81-90. https://doi.org/10.1016/S0022-1694(99) 00130-4

81. Gusman AJ, Mariño MA (1999) Analytical modeling of nitrogen dynamics in soils and groundwater. J Irrig Drain Eng 125:330337. https://doi.org/10.1061/(ASCE)0733-9437(1999)125:6(330)

82. Birkinshaw SJ, Ewen J (2000) Nitrogen transformation component for SHETRAN catchment nitrate transport modelling. J Hydrol 230:1-17. https://doi.org/10.1016/S0022-1694(00) 00174-8

83. Nolan BT, Hitt K, Ruddy B (2002) Probability of nitrate contamination of recently recharged ground waters in the conterminous United States. Environ Sci Tech 36:2138-2145. https://doi. org/10.1021/es0113854

84. Almasri MN, Kaluarachchi JJ (2004) Implications of on-ground nitrogen loading and soil transformations on groundwater quality management. J Am Water Res Assoc 40:165-186. https://doi.org/10.1111/j.1752-1688.2004.tb01017.x

85. Almasri MN, Kaluarachchi JJ (2007) Modeling nitrate contamination of groundwater in agricultural watersheds. J Hydrol 343:211-229. https://doi.org/10.1016/j.jhydrol.2007.06.016

86. Almasri MN (2007) Nitrate contamination of groundwater: a conceptual management framework. Environ Impact Assess Rev 27:220-242. https://doi.org/10.1016/j.eiar.2006.11.002

87. Li W, Zhai L, Lei Q, Wollheim WM, Liu J, Liu H, Hu W, Ren T, Wang $\mathrm{H}$, Liu S (2018) Influences of agricultural land use composition and distribution on nitrogen export from a subtropical watershed in China. Sci Total Environ 642:21-32. https://doi.org/10. 1016/j.scitotenv.2018.06.048

88. Xia Y, Ti C, She D, Yan X (2016) Linking river nutrient concentrations to land use and rainfall in a paddy agriculture-urban area gradient watershed in southeast China. Sci Total Environ 566(567):1094-1105. https://doi.org/10.1016/j.scitotenv.2016. 05.134

89. Ferrant S, Oehler F, Durand P, Ruiz L, Salmon-Monvioa J, Justes E, Dugast P, Probst A, Probst JL, Sánchez-Pérez JM (2011) Understanding nitrogen transfer dynamics in a small agricultural catchment: comparison of a distributed (TNT2) and a semi distributed (SWAT) modelling approaches. J Hydrol 406:1-15. https://doi.org/10.1016/j.jhydrol.2011.05.026

90. Arnold JG, Allen PM, Volk M, Williams JR, Bosch DD (2010) Assessment of different representations of spatial variability on SWAT model performance. Trans Am Soc Agri Biol Eng 53:1433-1443. https://doi.org/10.13031/2013.34913 
91. Liu RM, Xu F, Zhang PP, Yu WW, Men C (2016) Identifying nonpoint source critical source areas based on multi-factors at a basin scale with SWAT. J Hydrol 533:379-388. https://doi.org/ 10.1016/j.jhydrol.2015.12.024

92. Chen L, Zhong YC, Wei GY, Cai YP, Shen ZY (2014) Development of an integrated modeling approach for identifying multilevel non-point-source priority management areas at the watershed scale. Water Resour Res 50:4095-4109. https://doi.org/10.1002/ 2013WR015041

93. Shen ZY, Zhong YC, Huang Q, Chen L (2015) Identifying nonpoint source priority management areas in watersheds with multiple functional zones. Water Res 68:563-571. https://doi. org/10.1016/j.watres.2014.10.034

94. He B, Kanae S, Oki T, Hirabayashi Y, Yamashiki Y, Takara K (2011) Assessment of global nitrogen pollution in rivers using an integrated biogeochemical modeling framework. Water Res 45:2573-2586. https://doi.org/10.1016/j.watres.2011.02.011

95. Eltarabily MG, Negm AM, Yoshimura C, Saavedra OC (2017) Modeling the impact of nitrate fertilizers on groundwater quality in the southern part of the Nile Delta. Egypt Water Supp 17:561-570. https://doi.org/10.2166/ws.2016.162

96. Marinov I, Marinov AM (2014) A coupled mathematical model to predict the influence of nitrogen fertilization on crop, soil and groundwater quality. Water Resour Manag 28:5231-5246. https://doi.org/10.1007/s11269-014-0664-5

97. Burt TP, Howden NJ, Worrall F, Whelan MJ, Bieroza M (2011) Nitrate in United Kingdom rivers: policy and its outcomes since 1970. Environ Sci Technol 45:175-181. https://doi.org/10.1021/ es101395s

98. Wang L, Stuart ME, Bloomfield JP, Butcher AS, Gooddy DC, McKenzie AA, Lewis MA, Williams AT (2012) Prediction of the arrival of peak nitrate concentrations at the water table at the regional scale in Great Britain. Hydrol Process 26:226-239. https://doi.org/10.1002/hyp.8164

99. Wang L, Butcher AS, Stuart ME, Gooddy DC, Bloomfield JP (2013) The nitrate time bomb: a numerical way to investigate nitrate storage and lag time in the unsaturated zone. Environ Geochem Health 35:667-681. https://doi.org/10.1007/ s10653-013-9550-y

100. Lerner DN, Harris B (2009) The relationship between land use and groundwater resources and quality. Land Use Policy 26:S265-S273. https://doi.org/10.1016/j.landusepol.2009.09. 005

101. Tilman D, Fargione J, Wolff B, D'Antonio C, Dobson A, Howarth $R$, Schindler $D$, Schlesinger WH, Simberloff $D$, Swackhamer $D$ (2001) Forecasting agriculturally driven global environmental change. Science 292:281-284. https://doi.org/10.1126/science. 1057544

102. Sinha E, Michalak AM (2016) Precipitation dominates interannual variability of riverine nitrogen loading across the continental United States. Environ Sci Tech 50:12874-12884. https:// doi.org/10.1021/acs.est.6b04455

103. Schoumans OF, Chardon WJ, Bechmann ME, Gascuel-Odoux $C$, Hofman G, Kronvang B, Rubaek GH, Ulen B, Dorioz JM (2014) Mitigation options to reduce phosphorus losses from the agricultural sector and improve surface water quality: a review. Sci Total Environ 468(469):1255-1266. https://doi.org/10.1016/j. scitotenv.2013.08.061

104. Howarth R, Chan F, Conley DJ, Garnier J, Doney SC, Marino R, Billen G (2011) Coupled biogeochemical cycles: eutrophication and hypoxia in temperate estuaries and coastal marine ecosystems. Front Ecol Environ 9:18-26. https://doi.org/10.1890/ 100008

105. Kopacek J, Hejzlar J, Posch M (2013) Factors controlling the export of nitrogen from agricultural land in a large central
European catchment during 1900-2010. Environ Sci Tech 47:6400-6407. https://doi.org/10.1021/es400181m

106. Billen G, Thieu V, Garnier J, Silvestre M (2009) Modelling the N cascade in regional watersheds: the case study of the Seine, Somme and Scheldt rivers. Agric Ecosyst Environ 133:234-246. https://doi.org/10.1016/j.agee.2009.04.018

107. Seitzinger S, Harrison JA, Bohlke JK, Bouwman AF, Lowrance R, Peterson B, Tobias C, van Drecht G (2006) Denitrification across landscapes and waterscapes: a synthesis. Ecol App 16:20642090. https://doi.org/10.1890/1051-0761(2006)016[2064: DALAWA]2.0.CO;2

108. Hansen AT, Dolph CL, Foufoula-Georgiou E, Finlay JC (2018) Contribution of wetlands to nitrate removal at the watershed scale. Nat Geosci 11:127-132. https://doi.org/10.1038/ s41561-017-0056-6

109. Ouyang W, Song KY, Wang XL, Hao FH (2014) Non-point source pollution dynamics under long-term agricultural development and relationship with landscape dynamics. Ecol Indic 45:579589. https://doi.org/10.1016/j.ecolind.2014.05.025

110. Hill BH, Bolgrien DW (2011) Nitrogen removal by streams and rivers of the Upper Mississippi River basin. Biogeochem 102:183-194. https://doi.org/10.1007/s10533-010-9431-8

111. Wollheim WM, Vörösmarty CJ, Bouwman AF, Green $P$, Harrison J, Linder E, Peterson BJ, Seitzinger SP, Syvitski JPM (2008) Global $\mathrm{N}$ removal by freshwater aquatic systems using a spatially distributed, within-basin approach. Glob Biogeochem Cycl 22:GB2026. https://doi.org/10.1029/2007GB002963

112. Eghball B, Gilley JE, Baltensperger DD, Blumenthal JM (2002) Long-term manure and fertilizer application effects on phosphorus and nitrogen in runoff. Trans Am Soc Agric Biol Eng 45:687-694. https://doi.org/10.13031/2013.8850

113. Zhang YT, Wang HY, Liu S, Lei QL, Liu J, He JQ, Zhai LM, Ren TZ, Liu HB (2015) Identifying critical nitrogen application rate for maize yield and nitrate leaching in a Haplic Luvisol soil using the DNDC model. Sci Total Environ 514:388-398. https://doi. org/10.1016/j.scitotenv.2015.02.022

114. Zhou Y, Xu JF, Yin W, Ai L, Fang NF, Tan WF, Yan FL, Shi ZH (2017) Hydrological and environmental controls of the stream nitrate concentration and flux in a small agricultural watershed. J Hydrol 545:355-366. https://doi.org/10.1016/j.jhydrol.2016. 12.015

115. van Drecht G, Bouwman AF, Knoop JM, Meinardi C, Beusen A (2001) Global pollution of surface waters from point and nonpoint sources of nitrogen. Sci World 1(S2):632-641. https://doi. org/10.1100/tsw.2001.326

116. Alexander RB, Smith RA, Schwarz GE, Boyer EW, Nolan JV, Brakebill JW (2008) Differences in phosphorus and nitrogen delivery to the Gulf of Mexico from the Mississippi River Basin. Environ Sci Tech 42:822-830. https://doi.org/10.1021/es0716103

117. Wong CM, Williams CE, Pittock J, Collier U, Schelle P (2007) World's top 10 rivers at risk. WWF International, Gland, Switzerland. http://www.panda.org/about_wwf/what_we_do/fresh water/publications/index.cfm?uNewsID $=97680$

118. Duan SW, Xu F, Wang LJ (2007) Long-term changes in nutrient concentrations of the Changjiang River and principal tributaries. Biogeochemistry 85:215-234. https://doi.org/10.1007/ s10533-007-9130-2

119. Yan WJ, Zhang S, Sun P, Seitzinger SP (2003) How do nitrogen inputs to the Changjiang basin impact the Changjiang River nitrate: a temporal analysis for 1968-1997. Glob Biogeochem Cycl 17(4):1091. https://doi.org/10.1029/2002GB002029

120. Chen X, Strokal M, Kroeze C, Supit I, Wang M, Ma L, Chen X, Shi $X$ (2020) Modelling the contribution of crops to nitrogen pollution in the Yangtze River. Environ Sci Tech 54:11929-11939. https://doi.org/10.1021/acs.est.0c01333 
121. Dutta S (2012) Green Revolution revisited: the contemporary agrarian situation in Punjab, India. Soc Chang 42:229-247. https://doi.org/10.1177/004908571204200205

122. Bijay-Singh, Varinderpal-Singh (2012) Productivity and fertility of soils in the Indo-Gangetic Plains of South Asia. Arch Agron Soil Sci 58:S33-S40. https://doi.org/10.1080/03650340.2012. 693600

123. Katyal JC, Bijay-Singh, Vlek PLG, Buresh RJ (1987) Efficient nitrogen use as affected by urea application and irrigation sequence. Soil Sci Soc Am J 51:366-370. https://doi.org/10. 2136/sssaj1987.03615995005100020020x

124. Bijay-Singh, Yadvinder-Singh, Sekhon GS (1995) Fertilizer use efficiency and nitrate pollution of groundwater in developing countries. J Contam Hydrol 20:167-184. https://doi.org/10. 1016/0169-7722(95)00067-4

125. Bhardwaj A, Garg S, Sondhi SK, Taneja DS (2012) Nitrate contamination of shallow aquifer groundwater in the central districts of Punjab, India. J Environ Sci Eng 54:90-97

126. Agrawal GD, Lunkad SK, Malkhed T (1999) Diffuse agricultural nitrate pollution of groundwaters in India. Water Sci Tech 39:67-75. https://doi.org/10.1016/S0273-1223(99)00033-5

127. Chhabra A, Manjunath KR, Panigrahy S (2010) Non-point source pollution in Indian agriculture: estimation of nitrogen losses from rice crop using remote sensing and GIS. Int J Appl Earth Obs Geoinform 12:190-200. https://doi.org/10.1016/j.jag.2010. 02.007

128. Donner SD, Coe MT, Lenters JD, Twine TE, Foley JA (2002) Modeling the impact of hydrological changes on nitrate transport in the Mississippi River Basin from 1955 to 1994. Glob Biogeochem Cycle 16(3):1-19. https://doi.org/10.1029/2001GB0013 96

129. Showstack R (2000) Nutrient over-enrichment implicated in multiple problems in U.S. waterways. Eos Trans Am Geophys Union 81:497-499. https://doi.org/10.1029/00EO00358

130. NRC (National Research Council) (2012) Improving water quality in the Mississippi River Basin and Northern Gulf of Mexico: strategies and priorities. The National Academies Press, Washington. https://doi.org/10.17226/13029

131. Zillén L, Conley DJ, Andrén T, Andrén E, Björck S (2008) Past occurrences of hypoxia in the Baltic Sea and the role of climate variability, environmental change and human impact. Earth-Sci Rev 91:77-92. https://doi.org/10.1016/j.earscirev.2008.10.001

132. Stålnacke P, Grimvall A, Sundblad K, Tonderski A (1999) Estimation of riverine loads of nitrogen and phosphorus to the Baltic Sea, 1970-1993. Environ Monitor Assess 58:173-200. https:// doi.org/10.1023/A:1006073015871

133. Helsinki Commission (2004) The fourth Baltic Sea pollution load compilation (PLC-4). In: Baltic Sea environment proceedings. Helsinki Commission, Helsinki, Finland, vol 93, p 189

134. Asmala E, Saikku L, Vienonen S (2011) Import-export balance of nitrogen and phosphorus in food, fodder and fertilizers in the Baltic Sea drainage area. Sci Total Environ 409:4917-4922. https://doi.org/10.1016/j.scitotenv.2011.08.030

135. Thodsen $H$, Farkas $C$, Chormanski J, Trolle D, Blicher-Mathiesen G, Grant R, Engebretsen A, Kardel I, Andersen HE (2017) Modelling nutrient load changes from fertilizer application scenarios in six catchments around the Baltic Sea. Agriculture 7(5):41. https://doi.org/10.3390/agriculture7050041

136. Norse D (2005) Non-point pollution from crop production: global, regional and national issues. Pedosphere 15:499-508

137. Dinnes DL, Karlen DL, Jaynes DB, Kaspar TC, Hatfield JL, Colvin TS, Cambardella CA (2002) Nitrogen management strategies to reduce nitrate leaching in tile-drained Midwestern soils. Agron J 94:153-171. https://doi.org/10.2134/agronj2002.1530

138. Eagle AJ, Olander LP, Locklier KL, Heffernan JB, Bernhardt ES (2017) Fertilizer management and environmental factors drive
$\mathrm{N}_{2} \mathrm{O}$ and $\mathrm{NO}_{3}$ losses in corn: a meta-analysis. Soil Sci Soc Am J 81:1191-1202. https://doi.org/10.2136/sssaj2016.09.0281

139. Quemada M, Baranski $M$, Nobel-de Lange $M N J$, Vallejo $A$, Cooper JM (2013) Meta-analysis of strategies to control nitrate leaching in irrigated agricultural systems and their effects on crop yield. Agric Ecosyst Environ 174:1-10. https://doi.org/10. 1016/j.agee.2013.04.018

140. Lord El, Mitchell RDJ (1998) Effect of nitrogen inputs to cereals on nitrate leaching from sandy soils. Soil Use Manag 14:78-83. https://doi.org/10.1111/j.1475-2743.1998.tb00619.x

141. Lord El, Johnson PA, Archer JR (1999) Nitrate sensitive areas: a study of large scale control of nitrate loss in England. Soil Use Manag 15:201-207. https://doi.org/10.1111/j.1475-2743.1999. tb00089.x

142. Vervloet LS, Binning PJ, Børgesen CD, Højberg AL (2018) Delay in catchment nitrogen load to streams following restrictions on fertilizer application. Sci Total Environ 627:1154-1166. https:// doi.org/10.1016/j.scitotenv.2018.01.255

143. Choudhury ATMA, Kennedy IR (2005) Nitrogen fertilizer losses from rice soils and control of environmental pollution problems. Commun Soil Sci Plant Anal 36:1625-1639. https://doi. org/10.1081/CSS-200059104

144. Goulding K, Jarvis S, Whitmore A (2008) Optimizing nutrient management for farm systems. Philos Trans Royal Soc London Ser B Biol Sci 363:667-680. https://doi.org/10.1098/rstb.2007. 2177

145. Kay P, Edwards AC, Foulger M (2009) A review of the efficacy of contemporary agricultural stewardship measures for ameliorating water pollution problems of key concern to the UK water industry. Agric Syst 99:67-75. https://doi.org/10.1016/j. agsy.2008.10.006

146. Cameron KC, Di HJ, Moir JL (2013) Nitrogen losses from the soil/ plant system: a review. Ann Appl Biol 162:145-173. https://doi. org/10.1111/aab.12014

147. Xia L, Lam SK, Chen D, Wang J, Tang Q, Yan X (2017) Can knowledge-based $\mathrm{N}$ management produce more staple grain with lower greenhouse gas emission and reactive nitrogen pollution? A meta-analysis. Glob Chang Biol 23:1917-1925. https:// doi.org/10.1111/gcb.13455

148. Cerro I, Antigüedad I, Srinavasan R, Sauvage S, Volk M, SanchezPerez JM (2014) Simulating land management options to reduce nitrate pollution in an agricultural watershed dominated by an alluvial aquifer. J Environ Qual 43:67-74. https:// doi.org/10.2134/jeq2011.0393

149. Haas MB, Guse B, Fohrer N (2017) Assessing the impacts of Best Management Practices on nitrate pollution in an agricultural dominated lowland catchment considering environmental protection versus economic development. J Environ Manag 196:347-364. https://doi.org/10.1016/j.jenvman.2017.02.060

150. Nangia V, Gowda PH, Mulla DJ, Sands GR (2008) Water quality modeling of fertilizer management impacts on nitrate losses in tile drains at the field scale. J Environ Qual 37:296-307. https:// doi.org/10.2134/jeq2007.0224

151. Davis DM, Gowda PH, Mulla DJ, Randall GW (2000) Modeling nitrate nitrogen leaching in response to nitrogen fertilizer rate and tile drain depth or spacing for southern Minnesota, USA. J Environ Qual 29:1568-1581. https://doi.org/10.2134/jeq2000. $00472425002900050026 x$

152. Baksh AS, Hatfield JL, Kanwar RS, Ma L, Ahuja LR (2004) Simulating nitrate drainage losses from a Walnut Creek watershed field. J Environ Qual 33:114-123. https://doi.org/10.2134/jeq20 04.1140

153. Peña-Haro S, Llopis-Albert C, Pulido-Velazquez M, PulidoVelazquez D (2010) Fertilizer standards for controlling groundwater nitrate pollution from agriculture: El Salobral-Los Llanos 
case study. Spain J Hydrol 392:174-187. https://doi.org/10. 1016/j.jhydrol.2010.08.006

154. Gai X, Wang H, Liu J, Zhai L, Liu S, Ren T, Liu H (2014) Effects of feedstock and pyrolysis temperature on biochar adsorption of ammonium and nitrate. PLoS ONE 9(12):e113888. https://doi. org/10.1371/journal.pone.0113888

155. Novak JM, Busscher WJ, Watts DW (2012) Biochars impact on soil-moisture storage in an Ultisol and two Aridisols. Soil Sci 177:310-320. https://doi.org/10.1097/SS.0b013e31824e5593

156. Liu Q, Zhang Y, Liu B, Amonette JE, Lin Z, Liu G, Ambus P, Xie $Z$ (2018) How does biochar influence soil $N$ cycle? A metaanalysis. Plant Soil 426:211-225. https://doi.org/10.1007/ s11104-018-3619-4

157. Borchard N, Schirrmann M, Cayuela ML, Kammann C, WrageMönnig N, Estavillo JM, Fuertes-Mendizábal T, Sigua G, Spokas K, Ippolito JA, Novak J (2019) Biochar, soil and land-use interactions that reduce nitrate leaching and $\mathrm{N}_{2} \mathrm{O}$ emissions: a metaanalysis. Sci Total Environ 651:2354-2364. https://doi.org/10. 1016/j.scitotenv.2018.10.060

158. Liu R, Kang Y, Zhang C, Pei L, Wan S, Jiang S, Liu S, Ren Z, Yang Y (2014) Chemical fertilizer pollution control using drip fertigation for conservation of water quality in Danjiangkou Reservoir. Nutr Cycl Agroecosyst 98:295-307. https://doi.org/10.1007/ s10705-014-9612-2

159. Takeda I, Fukushima A (2006) Long-term changes in pollutant load outflows and purification function in a paddy field watershed using a circular irrigation system. Water Res 40:569-578. https://doi.org/10.1016/j.watres.2005.08.034

160. Krupa M, Tate KW, van Kessel C, Sarwar N, Linquist BA (2011) Water quality in rice growing watersheds in a Mediterranean climate. Agric Ecosyst Environ 144:290-301. https://doi.org/10. 1016/j.agee.2011.09.004

161. Lee H, Masuda T, Yasuda H, Hosoi Y (2014) The pollutant loads from a paddy field watershed due to agricultural activity. Paddy Water Environ 12:439-448. https://doi.org/10.1007/ s10333-013-0399-6

162. Min J, Shi W (2018) Nitrogen discharge pathways in vegetable production as non-point sources of pollution and measures to control it. Sci Total Environ 613(614):123-130. https://doi.org/ 10.1016/j.scitotenv.2017.09.079

163. Sun J, Mooney $\mathrm{H}$, Wu W, Tang $\mathrm{H}$, Tong $\mathrm{Y}, \mathrm{Xu} Z$ Z, Huang $\mathrm{B}$, Cheng $\mathrm{Y}$, Yang $X$, Wei D, Zhang F (2018) Importing food damages domestic environment: evidence from global soybean trade. Proc Natl Acad Sci USA 115:5415-5419. https://doi.org/10.1073/pnas. 1718153115

164. Mueller ND, Lassaletta L, Runck B, Billen G, Garnier J, Gerber JS (2017) Declining spatial efficiency of global cropland nitrogen allocation. Glob Biogeochem Cycle 31:245-257. https://doi. org/10.1002/2016GB005515

165. Zhang $X$ (2017) A plan for efficient use of nitrogen fertilizers. Nature 543:322-323. https://doi.org/10.1038/543322a

166. Paerl HW, Scott JT, McCarthy MJ, Newell SE, Gardner WS, Havens KE, Hoffman DK, Wilhelm SW, Wurtsbaugh WA (2016) It takes two to tango: when and where dual nutrient $(N \& P)$ reductions are needed to protect lakes and downstream ecosystems. Environ Sci Tech 50:10805-10813. https://doi.org/10.1021/acs.est. $6 \mathrm{~b} 02575$

167. Ma L, Feng S, Reidsma P, Qu F, Heerink N (2014) Identifying entry points to improve fertilizer use efficiency in Taihu Basin, China. Land Use Policy 37:52-59. https://doi.org/10.1016/j. landusepol.2013.01.008

168. CAST (Council for Agricultural Science and Technology) (2019) Reducing the impacts of agricultural nutrients on water quality across a changing landscape. Issue Paper 64, CAST, Ames, lowa, USA, p 20. https://www.cast-science.org/wp-content/uploads/ 2019/05/CAST_IP64_Nutrient-Loss.pdf
169. Mueller ND, Gerber JS, Johnston M, Ray DK, Ramankutty N, Foley JA (2012) Closing yield gaps through nutrient and water management. Nature 490:254-257. https://doi.org/10.1038/ nature 11420

170. Dumanski J, Peiretti R, Benites J, McGarry D, Pieri C (2006) The paradigm of conservation agriculture. Proc World Assoc Soil Water Conserv P1:58-64

171. Daryanto S, Wang L, Jacinthe PA (2017) Impacts of no-tillage management on nitrate loss from corn, soybean and wheat cultivation: a meta-analysis. Sci Rep 7:12117. https://doi.org/ 10.1038/s41598-017-12383-7

172. Lawniczak AE, Zbierska J, Nowak B, Achtenberg K, Grześkowiak K, Kanas K (2016) Impact of agriculture and land use on nitrate contamination in groundwater and running waters in centralwest Poland. Environ Monit Assess 188:172. https://doi.org/10. 1007/s10661-016-5167-9

173. Stuart ME, Good DC, Bloomfield JP, Williams AT (2011) A review of the potential impact of climate change on future nitrate concentrations in groundwater of the UK. Sci Total Environ 409:2859-2873. https://doi.org/10.1016/j.scitotenv.2011.04. 016

174. Dore MH (2005) Climate change and changes in global precipitation patterns: what do we know? Environ Int 31:1167-1181

175. Trenberth KE (2011) Changes in precipitation with climate change. Clim Res 47:123-138

176. Mas-Pla J, Menció A (2019) Groundwater nitrate pollution and climate change: learnings from a water balance-based analysis of several aquifers in a western Mediterranean region (Catalonia). Environ Sci Pollut Res 26:2184-2202. https://doi.org/10. 1007/s11356-018-1859-8

177. Li T, Zhang W, Yin J, Chadwick D, Norse D, Lu Y, Liu X, Chen X, Zhang F, Powlson D, Dou Z (2018) Enhanced-efficiency fertilizers are not a panacea for resolving the nitrogen problem. Glob Change Biol 24(2):e511-e521. https://doi.org/10.1111/ gcb.13918

178. Zhang $X$, Davidson EA, Mauzerall $D L$, Searchinger TD, Dumas $P$, Shen $Y$ (2015) Managing nitrogen for sustainable development. Nature 528:51-59. https://doi.org/10.1038/nature15743

179. Yu C, Huang $X$, Chen H, Godfray HCJ, Wright JS, Hall JW, Gong P, Ni S, Qiao S, Huang G, Xiao Y (2019) Managing nitrogen to restore water quality in China. Nature 567:516-520. https://doi. org/10.1038/s41586-019-1001-1

180. Cui Z, Zhang H, Chen X, Zhang C, Ma W, Huang C, Zhang W, Mi G, Miao Y, Li X, Gao Q (2018) Pursuing sustainable productivity with millions of smallholder farmers. Nature 555:363-366. https://doi.org/10.1038/nature25785

181. Weersink A, Fraser E, Pannell D, Duncan E, Rotz S (2018) Opportunities and challenges for big data in agricultural and environmental analysis. Ann Rev Resour Econ 10:19-37. https://doi. org/10.1146/annurev-resource-100516-053654

182. Delgado JA, Short NM Jr, Roberts DP, Vandenberg B (2019) Big data analysis for sustainable agriculture on a geospatial cloud framework. Front Sustain Food Syst 3:54. https://doi.org/10. 3389/fsufs.2019.00054

183. Basso B, Shuai G, Zhang J, Robertson GP (2019) Yield stability analysis reveals sources of large-scale nitrogen loss from the US Midwest. Sci Rep 9:5774. https://doi.org/10.1038/ s41598-019-42271-1

184. Chowdary VM, Rao NH, Sarma PBS (2005) Decision support framework for assessment of non-point-source pollution of groundwater in large irrigation projects. Agric Water Manag 75:194-225. https://doi.org/10.1016/j.agwat.2004.12.013

185. Pathak $H$, Chattarjee D, Saha S (2019) Fertilizer and environmental pollution: from problem to solution. Indian J Fert $15: 262-280$ 
186. Delgado JA, Vandenberg B, Neer D, D'Adamo R (2019) Emerging nutrient management databases and networks of networks will have broad applicability in future machine learning and artificial intelligence applications in soil and water conservation. J Soil Water Conserv 74:113A-118A. https://doi.org/10. 2489/jswc.74.6.113A

187. van Vliet MT, Flörke M, Harrison JA, Hofstra N, Keller V, Ludwig F, Spanier JE, Strokal M, Wada Y, Wen Y, Williams RJ (2019) Model inter-comparison design for large-scale water quality models. Curr Opin Environ Sustain 36:59-67
188. Tang T, Strokal M, van Vliet MT, Seuntjens $P$, Burek $P$, Kroeze $C$, Langan S, Wada Y (2019) Bridging global, basin and local-scale water quality modeling towards enhancing water quality management worldwide. Curr Opin Environ Sustain 36:39-48

Publisher's Note Springer Nature remains neutral with regard to jurisdictional claims in published maps and institutional affiliations. 